NBER WORKING PAPER SERIES

\title{
WERE NINETEENTH-CENTURY INDUSTRIAL WORKERS PERMANENT INCOME SAVERS?
}

Howard Bodenhorn

Working Paper 23948

http://www.nber.org/papers/w23948

\author{
NATIONAL BUREAU OF ECONOMIC RESEARCH \\ 1050 Massachusetts Avenue \\ Cambridge, MA 02138 \\ October 2017
}

I thank Ray Cohn and Richard Sutch for comments, and Babur De Los Santos for advice on the econometrics. Veronica Aoki Santarosa, Denica Karadzhova, Dimitar Marmarov, and Justus Staisiunas for exceptional research assistance. The views expressed herein are those of the author and do not necessarily reflect the views of the National Bureau of Economic Research.

NBER working papers are circulated for discussion and comment purposes. They have not been peer-reviewed or been subject to the review by the NBER Board of Directors that accompanies official NBER publications.

(C) 2017 by Howard Bodenhorn. All rights reserved. Short sections of text, not to exceed two paragraphs, may be quoted without explicit permission provided that full credit, including () notice, is given to the source. 
Were Nineteenth-Century Industrial Workers Permanent Income Savers?

Howard Bodenhorn

NBER Working Paper No. 23948

October 2017

JEL No. D15,N21

\begin{abstract}
$\underline{\text { ABSTRACT }}$
Theories of household saving posit that households add to or draw down wealth to equalize the discounted presented value of consumption over time. This paper examines the extent to which nineteenth-century urban American industrial workers used saving and dissaving to smooth consumption in response to unanticipated, plausibly exogenous, shocks to income. Information on the expected and unexpected number of days unemployed is used to construct estimates of transitory income. The data are then used to estimate the marginal propensity to save from transitory income, and the results are broadly consistent with Friedman's (1957) permanent income hypothesis.
\end{abstract}

\author{
Howard Bodenhorn \\ John E. Walker Department of Economics \\ College of Business \\ 201-B Sirrine Hall \\ Clemson University \\ Clemson, SC 29634 \\ and NBER \\ bodenhorn@gmail.com
}




\section{Introduction}

Keynes (1936) offers eight reasons for saving. They save as a precaution against uncertain future income and expenditures, for retirement, to leave a bequest, to increase their economic independence, to invest in a business venture, or because they have a preference for future over present consumption. People also save when the interest rate exceeds their personal rate of time preference, and, perhaps, out of sheer miserliness. Despite Keynes' signal contributions to thinking about saving, modern economic studies of savings are more likely to be motivated by the life cycle and permanent income hypotheses developed in the 1950s (Modigliani and Brumberg 1954; Friedman 1957), or the buffer stock theory of the 1990s (Deaton 1991; Carroll 1992). The central insight emerging from these later hypotheses are that rational, forward-looking people equalize the marginal utility of expenditure over time because lifetime welfare is maximized if the discounted utility of consumption is equal in all periods. One implication is that households tend to smooth consumption over time. A second is that consumption smoothing involves household saving (and dissaving) and that the fraction of permanent income saved differs from the fraction of transitory income saved.

One difficulty in investigating whether historical actors were permanentincome savers is separating the permanent and transitory components of income. A second is the relatively generosity of the modern welfare state in its maintenance of household consumption in the face of unanticipated income shocks. The late nineteenth-century offers a unique opportunity to investigate whether household saving behaviors are consistent with the permanent income hypothesis. The welfare state was a later development and working-class manufacturing incomes were uncertain so that households saved to avoid severe consumption shortfalls in lowincome periods. It was not uncommon for many manufacturing enterprises to operate only for part of the year. In some industries plant closings were predictable, such as in glass blowing in New Jersey in which factories closed in July and August, and workers earned higher wages that partly compensated them for the inconvenience (New Jersey Bureau of Statistics of Labor and Industry 1883-1888, hereafter NJBSLI, Atack, Bateman, and Margo 2002; Averett, Bodenhorn, and 
Staisiunas 2005). But unexpected plant closings, as well as illnesses or industrial accidents created substantial divergences between the anticipated and actual number of days worked per year and, thus, substantial divergences between expected and realized annual incomes (Fishback 1998; Murray 2007). One jeweler, for example, reported that "You will notice in my report of earnings that the number of days lost is large; also that my expenditure has been greater than my income, which had been entirely due to the loss of time" (NJBSLI 1883, 122). This study takes advantage of unanticipated unemployment to estimate the permanent and transitory components of observed annual incomes to test the predictions of the permanent income hypotheses in an historical context.

Although Progressive Era reformers worked to create a safety net for industrial workers, the presumption remained that workers needed to provide for themselves. In a now infamous sermon delivered during an 1877 railroad strike during which it was reported that strikers and their families were forced to live on a dollar a day, or effectively a bread and water diet, Henry Ward Beecher thundered that "the man who cannot live on bread and water is not fit to live" (quoted in Rossiter 1955, p. 157). ${ }^{1}$ In such a political, economic and social climate, it was incumbent on workingmen who wished to maintain their families' living standards to transfer income from flush to hard times. Intertemporal transfers presuppose a combination of forward-looking behavior (a demand for saving) and some type of formal or informal financial institution to facilitate the transfer (a supply of saving capacity).

Modern empirical investigations of life-cycle consumption and saving find that the predictions hold even with imperfect capital markets. The principal imperfection in modern times is that young households generally prefer to consume more early in life but do not because capital markets make present borrowing against future income and wealth uneconomic (Browning and Lusardi 1996). Capital market imperfections emerge in modern markets despite the gamut of consumption-

1 Following withering criticism for his insensitivity, Beecher later clarified his earlier comments in that: "I do not say that a dollar a day is enough to support a workingman: but I do say that it is enough to support a man - that is to say, if it gives him bread. Not that a man should eat bread forever ... it is a mere question of how he will carry himself during the emergency" (Beecher 1877, p. 92 emphasis in original). 
smoothing and saving vehicles open to modern households: demand and savings accounts at commercial banks, thrifts, credit unions and trust companies; online brokerage accounts; employer-sponsored pensions and retirement accounts; life insurance; payday and title loans; pawn shops and many, many others. Before the mid-nineteenth century the principal "imperfection" was that there were few formal financial institutions available to assist working-class households in the accumulation of financial assets. By century's end, mutual savings banks, industrial life insurance companies, beneficial societies, and building and loan associations mobilized and invested household savings, allowing households to smooth consumption over time.

This paper exploits data on the income, expenditures, and days worked of New Jersey's late nineteenth-century industrial workers to better understand whether and how these workers responded to income shocks. Factories closed for longer than usual periods, unexpected labor actions, and extended illnesses meant fewer days worked per year than anticipated for many workers. The paper examines whether and how much workers saved from current deviations in transitory income in anticipation of future income shocks.

Using five cross sections of income, expenditure, and days worked data collected by the New Jersey Bureau of Statistics of Labor and Industry conducted between 1883 and 1888, this paper estimates the marginal propensities to save out of transitory and permanent income. This study, motivated by Friedman's (1957) permanent income hypothesis, the data reveal that the marginal propensities to save out of transitory income were between about one-half and two-thirds, or about the same values found by Paxson (1992) in her study of Thai farmers. This finding suggests that late nineteenth-century industrial workers used savings to smooth consumption. Workers saved a large fraction of current transitory income to see them through periods of low earnings.

The principal challenge of the paper is decomposing income into its transitory and nontransitory components. One contribution paper is that it uses pooled cross section-time series data on individual work days lost and establishment averages of work days lost to directly estimate transitory income due to employment shocks. A principal prediction of the permanent income-life cycle models of household consumption is that income shocks that affect current income will not 
affect current consumption, which is a function of households' permanent incomes. Thus, that fraction of household income determined by an employment shock provides a measure of transitory income. Once estimates of transitory income are estimated, those estimates are used to generate estimates of the marginal propensity to save out of transitory and nontransitory income. The resulting estimates are consistent with a weak version of the permanent income hypothesis.

A second contribution of this paper is the measurement of savings. The existing economic history of savings relies on data that may not capture representative savings rates. North (1979) observed that growing industrial economies create a need for financial saving, but relatively little is known about how, or even whether, urban-industrial households saved. Evidence from the New Jersey surveys imply an average savings rate between $8.5 \%$ and $14.8 \%$ of current income, which are slightly lower than the $12 \%$ to $17 \%$ percent estimated by Alter et al (1994), who include only those saver, and considerably lower than the saving rate generated by Sutch (2011) for industrial workers in Kansas in 1885, which excludes dissavers and workers reporting zero saving.

A third contribution of the paper is that the data are drawn from an era that witnessed the rise and rapid expansion of formal savings institutions - savings banks, industrial life companies, and fraternal benefit societies - and shows that workingclass households took advantage of these expanded opportunities. Data reported in the NJBSLI (1886) labor survey reveal that the average annual working-class household expenditure on life insurance and fraternal benefit society (sickness insurance) dues was $\$ 14.62$ or about $1.9 \%$ of average annual household income, and sufficient to purchase a basic sickness insurance policy and a $\$ 200$ burial insurance policy. And approximately one-half of working-class households had such policies because, as a Hudson County freight handler explained in an earlier survey: most workers lived "in mortal dread of sickness and death, and there is scarcely a man among them that does not owe a heavy physician's bill” (NJBSLI 1883, 130). Regular dues paid into a beneficial society relieved a working man of the bill, if not the dread. One-seventh reported a savings bank account with an average account balance of $\$ 240$. One-quarter of households belonged to a building and loan society, which was a popular path to home ownership (Schoenfeld 1925). Ultimately, this paper offers 
fresh insights into the Progressive Era. Industrial workers were not at the mercy of forces beyond their understanding or control. Workers could envision, even anticipate, periods of low employment and income and save and dissave in a fashion consistent with modern theories of consumption and saving behaviors.

\section{A permanent-income approach to saving}

The nature of the data is such that most early budget studies consider the extent to which a household's current consumption depends on current income (Brady and Friedman 1947). But Friedman (1957) argues that current consumption depends on current wealth, which depends on past, current, and future income and the time path of interest rates. Current consumption, then, depends on permanent income, not current income. The corollary is that current saving depends on current income, current wealth and the interest rate. When the future is certain, households hold, add to, or draw down wealth to smooth consumption over time, depending on the household's time preferences, its expected future incomes, and expected interest rates. Households hold most of their wealth as relatively illiquid human capital, but also hold a liquid reserve fund against unexpectedly low earnings in some periods (Ehrenberg and Smith 2008). Households hold cash and other liquid assets to maintain consumption during emergencies and when current income falls below expected income.

A parsimonious derivation of the household's saving decision from the permanent income hypothesis follows from Friedman's (1957, p.26) three-equation system (suppressing the time subscripts on current and transitory variables for convenience):

$$
\begin{aligned}
& \mathrm{c}_{\mathrm{p}}=\mathrm{k}(\mathrm{r}, \mathrm{u}, \mathrm{w}) \cdot \mathrm{y}_{\mathrm{p}} \\
& \mathrm{y}=\mathrm{y}_{\mathrm{p}}+\mathrm{y}_{\mathrm{t}} \\
& \mathrm{c}=\mathrm{c}_{\mathrm{p}}+\mathrm{c}_{\mathrm{t}},
\end{aligned}
$$

where $\mathrm{c}$ is current consumption, and $c_{\mathrm{p}}$ and $c_{t}$ are its permanent and transitory components; $\mathrm{y}$ is current income, and $\mathrm{y}_{\mathrm{p}}$ and $\mathrm{y}_{\mathrm{t}}$ are its permanent and transitory components. Permanent consumption $\mathrm{c}_{\mathrm{p}}$ is the product of permanent income and the proportional multiplier $\mathrm{k}$, which is a function of the interest rate $(\mathrm{r})$, preferences (u), and wealth (w). 
If we define current saving as $s=y-c$, substitute equations (1) through (3) and rearrange terms, saving can be written as:

$$
\mathrm{s}=(1-\mathrm{k}) \cdot \mathrm{y}_{\mathrm{p}}+\mathrm{y}_{\mathrm{t}}-\mathrm{c}_{\mathrm{t}} .
$$

An important implication of the hypothesis is that the marginal saving rate from permanent income $(1-\mathrm{k})$ is less than the marginal saving rate from transitory income (1). In the limit, $c_{t} \approx 0$ and $\mathrm{k}=1$, which further imply that all transitory income is saved and that permanent consumption does not respond to changes in nontransitory income. Further, under certainty $\mathrm{dy}_{\mathrm{p}}=0$, and under uncertainty $E\left[\mathrm{dy}_{\mathrm{p}}\right]$ $=0$, which imply that saving and dissaving follows from shocks to transitory income.

Friedman posits the following additional conditions:

(5) $\rho_{\text {yt yp }}=\rho_{\text {ct cp }}=\rho_{\text {yt ct }}=\rho_{\text {cp y }}=0$,

where $\rho$ is the correlation coefficient between the relevant variables. Friedman (1957, p. 27) notes that the assumptions that permanent and transitory incomes are uncorrelated and that permanent and transitory consumption are uncorrelated follow from their definitions. The third assumption - that transitory income and transitory consumption are uncorrelated - is a strong one, but one that introduces substantive content into the hypothesis and makes it potentially refutable. The common notion of saving as a residual makes the third assumption plausible. The saving-as-residual notion implies that consumption is determined by long-term factors, so that transitory income shocks lead primarily to additions to or subtraction from wealth.

The fourth assumption - that permanent consumption and current income are uncorrelated - is central to the permanent income hypothesis and is vital to understanding the household's decision to save. "The resources that a representative consumer allocates to consumption at any age," writes Modigliani (1986, p. 299) "will depend only on his life resources ... and not at all to income accruing currently." Modigliani held that households smooth consumption and that shortterm saving responds only to stochastic deviations between current and expected or transitory - income. Short-term fluctuations in income do not induce deviations from the anticipated consumption path, and strong versions of the permanent 
income hypothesis predict that fluctuations in current saving are driven entirely by changes in transitory income (Paxson 1992, p. 26). ${ }^{2}$

The empirical challenges lies in decomposing observed annual income into its transitory and nontransitory components, and then determining the amount saved from each component. ${ }^{3}$ Following Paxson (1992), I assume that the saving of household $j$ residing in county $c$ and employed in industry $i$ in year $t$ is a linear function of permanent income $\left(\mathrm{Y}_{\text {jirt }}\right)$ and transitory income $\left(\mathrm{Yt}_{\mathrm{jirt}}\right)$. It is important to note that the empirical analog of permanent income estimated here is not the permanent income ( $=$ annuity value of lifetime wealth) discussed in the theoretical literature; rather it is the short-term expected income conditional on a household's characteristics in year t. Transitory income is the amount of household income realized due to positive and negative employment shocks experienced by the household head due to differences between reported and expected illness, reported and expected slack time, and work days missed for other reasons. The precise definition of employment shocks is provided below.

Long-term factors, such as family size and other household characteristics, $\mathrm{F}_{\text {jirt, }}$, influence household saving behavior. Studies of saving find that households with more children will save less because the current income of young household members is less than the annuity value of lifetime wealth (Deaton 2005). In addition, to the extent that parents view children as sources of support in retirement, current expenditures on children may substitute for current saving. The family variables include a series of dummy variables related to family size - single individual, two people, three people, and so forth. An additional dummy variable is included that equals one if a family member other than the household head reports earning income during the year; and zero otherwise. Neighborhood factors, $\mathrm{N}_{\mathrm{jirt}}$, may be determinants of saving. The principal neighborhood feature included here is ready

\footnotetext{
2 The buffer stock theory also predicts a relatively high propensity to consume out of transitory income (Carroll 1997. p. 3), and, unlike other models assumes consumers are impatient. Savings are a "necessary evil" - foregone current consumption opportunities - that are held as insurance against an uncertain future (Deaton 1992, p. 264). Because the data provide no information on wealth the analysis follows the permanent income approach, which does not require information about lifetime wealth.

3 I follow Paxson (1992) in referring to nontransitory income as permanent income, but it is important to note that they are not the same. Permanent income is difficult to determine absent detailed information on households' wealth and other characteristics.
} 
access to a formal financial institution, namely a mutual savings bank or a building and loan association (New Jersey Department of State 1882-1889).

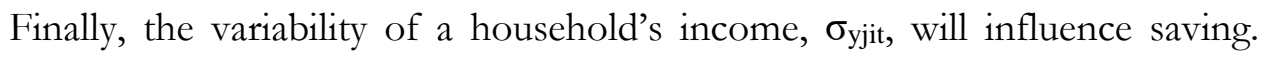
Absent panel data, it is difficult to measure income variability. The approach taken here is to proxy for $\sigma_{y j i t}$ with a variable that measures the variance of slack days, or the days in which workers are unable to work because their place of employment closes or slows production, leading to layoffs. These statistics are drawn from separate surveys of establishments conducted by NJBSLI (1883-1885). The establishment surveys inquired into total employment, average wages, hours per day, and the number of days lost to lack of work. Because they are drawn from separate surveys, the establishment-level measure of slack days differs from the workersupplied estimates and is not subject to the same measurement error as the employee-reported time lost. (Appendix 1 reports summary statistics of establishment- and employee-reported slack days.) The measure is such that it does not vary across households employed in the same industry or across time.

These considerations yield the following saving equation:

$$
S_{j i r t}=\alpha_{0}+\alpha_{1} \mathrm{Yp}_{\mathrm{jirt}}+\alpha_{2} \mathrm{Yt}_{\mathrm{jirt}}+\alpha_{3} \mathrm{~N}_{\mathrm{jirt}}+\alpha_{4} \mathrm{~F}_{\mathrm{jirt}}+\alpha_{5} \sigma_{\mathrm{Yjir}}+\eta_{\mathrm{jirt}}
$$

Paxson (1992) shows that a saving equation linear in permanent and transitory income and the variance of income is consistent with a lifetime utility function that is additively separable and is either quadratic in the arguments or exhibits constantabsolute-risk-aversion. A permanent income approach suggests that the marginal saving rate from permanent income, $\alpha_{1}$, will be approximately zero, and that the marginal saving rate from transitory income, $\alpha_{2}$, will be approximately one. The coefficient on the variability of income, $\alpha_{5}$, is ambiguous, though it is not unreasonable to posit that households with highly variable incomes save more. If $\alpha_{5}$ $>0$, the results are consistent with constant absolute risk aversion.

The difficulty in estimating a saving equation like Eq. (6) is that it requires information on transitory and permanent income, which is unobserved. Because the budget surveys provide no information about current or lifetime wealth, direct 
estimation of permanent income is problematic. It is possible, however, to estimate a transitory component of current income and to construct a short-term analog to permanent income. To construct an estimate of transitory income, assume that it can be expressed as:

$$
\mathrm{Yt}_{\mathrm{jirt}}=\varphi_{\mathrm{tt}}+\beta_{\mathrm{t}} \mathrm{Xt}_{\mathrm{jirt}}+\varepsilon_{\mathrm{tjirt}}
$$

where $\varphi_{\mathrm{tt}}$ is a transitory year fixed effect common to all households. $\mathrm{X}_{\mathrm{jirt}}$ consists of a set of household specific variables affecting transitory income.

The budget surveys report the number of days lost in the past year to illness, to slack days (establishment closings or slowdowns), and to "other causes" and the variables included in $\mathrm{X}$ that determine transitory income are deviations from average values for sick days, slack days, and other days lost, as well as the squared values of each, to capture any nonlinearity in sick days on income. Slack day deviations are estimated in two ways: (1) slack days reported by individual respondents less the mean value of slack days reported by all respondents employed in the same industry; and, (2) slack days reported by the worker less the mean value of slack days as reported by employers at the establishment level. (See Appendix 1 for a comparison.) Sick day deviations are also calculated in two ways: (1) individual-reported sick days less the average number of sick days for workers in the same industry; and, (2) as individual reported sick days less $5 \%$ of the 275 days of full-time, year-round employment ( $=50$ weeks at 5.5 days per week). In the 1884 establishment reports, a shoe manufacturer and a rubber manufacturer state that workers typically missed about $5 \%$ of time to illness and the second estimate follows their observation (NJBSLI 1884).

Other days missed are estimated as the individual-reported other days lost less the average other days lost for workers in the same industry. Industry-specific averages are used to create the fraction of days lost by cause rather than all-worker averages because some industries - such as hat making - involve the use of dangerous materials that may lead to higher sickness rates; and the other days lost variable will be specific to industries if strikes or other job actions occur in an industry, as occurred in the shoe-making industry in 1885 (NJBSLI 1885). Equation 
(8) provides a general definition of the principal variables that make up Xt, namely Lost days deviation and its square.

(8) Lost days deviation $=($ individual sick days - industry sick days $)+$ (individual slack days - industry slack days) + (individual "other" days - industry "other" days).

Estimates of a short-term analog of permanent income follow a parallel strategy. Assume that a household's permanent income can be expressed as:

$$
\mathrm{Y}_{\mathrm{jirt}}=\varphi_{\mathrm{pt}}+\varphi_{\mathrm{c}}+\varphi_{\mathrm{i}}+\beta_{\mathrm{p}} \mathrm{Z}_{\mathrm{jirt}}+\varepsilon_{\mathrm{pjirt}}
$$

where $\varphi_{p t}$ is a year fixed effect, $\varphi_{c}$ is a county-of-residence fixed effect, and $\varphi_{i}$ is an industry-of-employment fixed effect. The vector $Z \mathrm{p}_{\mathrm{jirt}}$ includes two types of individual factors that are likely to influence permanent income: the skill level of the survey respondent, as well as a proxy for the likely length of the respondent's career.

People who make greater investments in human capital can reasonably expect higher lifetime or permanent income (Ehrenberg and Smith 2008). Two strategies are followed to assign workers to skill levels. Reiss' (1961) industry-job title classification categorizes jobs into three broad skill levels: craft or skilled workers; operatives; and laborers. Skill category dummy variables for all but common laborers are included in the income regressions. Duncan's classification also includes a socioeconomic prestige score for each industry/job description that varies from zero to 100. These prestige scores are used to construct a second measure of human capital: quintiles of the prestige scores are first estimated, then dummy variables for the four highest quintiles are included in the income regressions.

Besides human capital investments a second feature of most jobs that bear on the permanent income anticipated from choosing that occupation is the expected length of career. Jobs in which workers remain productive for longer periods expect higher lifetime incomes, ceteris paribus, and Progressive Era reformers expressed concerns over the connection between the length of many workers' careers and the length of the working day, workplace safety, and the long-term health consequences 
of certain occupations. To better understand workplace safety and the health consequences of manufacturing occupations respondents were asked to provide information on the age at which workers in their job start to "decline," interpreted here as the onset of age-related productivity decline. These responses, which ranged from age 25 to 65 , were categorized into a series of 5-year dummy variables centered on the fives (i.e., $32.5<z 35 \leq 37.5,37.5<z 40 \leq 42.5$, etc.). The excluded category is $z 40$, which was the most commonly reported age-at-decline and is consistent with known high-health-risk occupations, such as potters and hatters who were exposed to lead, mercury, and other dangerous chemicals. Carpenters, on the other hand, reported an average age at decline of 57 years; bricklayers, 56 years (Ransom and Sutch 1995).

The expected sign on the age-at-decline effects are ambiguous. If workers have perfect foresight and markets are competitive and frictionless, workers in dangerous or unhealthy occupations should receive a compensating differential such that, holding all else constant, permanent incomes are similar for similar skills, education, and so on. Workers in hazardous occupations and expecting shorter careers should earn more at each age than workers in less hazardous jobs. If markets do not compensate for hazardous or unhealthful workplaces, which concerned Progressive Era reformers, there may not be a consistent relationship between income and age at decline. Fishback (1998) and Averett et al (2005) find that Progressive-Era workers were partly compensated for job hazards and unemployment risk.

Equations (7) and (9) provide an estimating equation for total income (Eq. 10):

(10) $\mathrm{Y}_{\mathrm{irt}}=\varphi_{\mathrm{t}}+\varphi_{\mathrm{c}}+\varphi_{\mathrm{i}}+\beta_{\mathrm{p}} \mathrm{Zp}_{\mathrm{jirt}}+\beta_{\mathrm{t}} \mathrm{Xt}_{\mathrm{jirt}}+\beta_{1} \mathrm{~N}_{\mathrm{jirt}}+\beta_{2} \mathrm{~F}_{\mathrm{jirt}}+\varepsilon_{\mathrm{jirt}}$

and equations (7) and (9) can also be substituted into the structural saving equation (Eq 6), which yields an augmented structural equation:

(11) $S_{j i r t}=\alpha_{0 t}+\alpha_{1}\left[\varphi_{c}+\varphi_{i}+\beta_{p} Z p_{j i r t}\right]+\alpha_{2}\left[\beta_{t} X t_{j i r t}\right]+\alpha_{3} N_{j i r t}+\alpha_{4} F_{j i r t}+\alpha_{5} \sigma_{Y j i r}$ $+\eta_{\mathrm{jirt}}$ 
where $\varphi_{\mathrm{t}}=\varphi_{\mathrm{tt}}+\varphi_{\mathrm{pt}}, \alpha_{0 \mathrm{t}}=\alpha_{0}+\alpha_{1} \varphi_{\mathrm{pt}}+\alpha_{2} \varphi_{\mathrm{tt}}$, the error term in the income equation is $\varepsilon_{\mathrm{irt}}=\varepsilon_{\mathrm{tj} i \mathrm{rt}}+\varepsilon_{\mathrm{pjirt}}$, and $\eta_{\mathrm{jirt}}$ is the error term in the saving equation. A reduced-form saving equation can be written as:

(12) $S_{j i r t}=\gamma_{t}+\gamma_{c}+\gamma_{i}+\gamma_{1} Z_{p_{j i r t}}+\gamma_{2} X_{j i r t}+\gamma_{3} N_{j i r t}+\gamma_{4} F_{j i r t}+v_{j i r t}$.

The reduced-form saving equation does not contain the income variance term, $\sigma_{Y j i r}$, because it is collinear with the determinants of permanent income in that it does not vary across individuals within an industry and is defined such that it forms a linear combination of the industry dummy variables. The income-variance effect, therefore, is captured in the industry fixed effects, $\gamma_{\mathrm{i}}$.

The first test of whether late-nineteenth-century working-class households were permanent-income-type savers is to generate estimates of the reduced-form income (Eq. 10) and saving (Eq. 12) equations. One implication of the permanent income hypothesis is that $\gamma_{2}$, the marginal rate of saving from transitory income, should equal 1, and that the marginal effects of the transitory elements in $\mathrm{Xt}_{\text {jirt }}$ on saving should be the same as they are on income. That is, if the permanent-income hypothesis holds, $\gamma_{2}=\beta_{\mathrm{t}}$. Transitory employment shocks, whether due to sickness, slack days, or other causes should influence saving and income in identical fashion because the marginal propensity to consume from transitory income is zero.

An additional implication of the permanent income hypothesis for the reduced-form estimates is that $\gamma_{1}$, the marginal rate of saving from permanent income is zero. This implication predicts that the marginal effects of all the variables included in $Z_{\text {jirt }}$ should have no effect on saving, or that the elements of $\gamma_{1}$ that correspond to permanent income equal zero. While it is plausible that location, industry, family structure, and age at decline all influence permanent income in some 
way, the strongest test will be whether the estimated coefficients on the human capital variables are zero. ${ }^{4}$

Estimates of the structural saving model (Equation [6]) provide a second test of the hypothesis. Following Paxson (1992) I implement a two-step model in which Equation [10], the reduced-form income equation, is first estimated by ordinary least squares to form estimates of transitory and permanent income. Household saving is then regressed on the resulting estimates of permanent ( $\left.\mathrm{Y}_{\mathrm{j} i r t}\right)$ and transitory ( $\left.\mathrm{Yt}_{\mathrm{jir}}\right)$ incomes. A two-step estimation procedure is computationally simple, though it is not statistically efficient and will yield consistent estimates only under restrictive conditions. Barro (1977) argues that efficiency can be improved by joint estimation of the original income and second-step equations to correct for the correlation between the error terms, but Pagan (1984) doubts whether doing so notably improves efficiency or consistency. Despite the econometric concerns surrounding such estimates, the results are reported because they offer some insight into the extent to which households were permanent income savers.

Finally, the third test of the permanent income saving hypothesis estimates the income and savings equations (10) and (11) simultaneously by maximum likelihood. This maximum likelihood estimator is effectively the same as the reducedform estimators, subject to the nonlinear restrictions on the coefficients that appear in Equation (11). These estimates are used to test the overidentifying restrictions on the model, namely that the effects of each of the transitory income variables (e.g., deviation in days lost and its square) and permanent income variables is proportional to two-step coefficients consistent with estimation of Equation (6). The factor of proportionality for the transitory variables is $\alpha_{2}$; and the factor of proportionality for the permanent income variables is $\alpha_{1}$.

\section{Data}

The principal source of evidence on household saving behaviors is five reports issued by the NJBSLI between 1883 and 1888, except 1887 when no survey was conducted. Modeled after the Massachusetts labor bureau headed by Carroll D.

4 Friedman (1957, pp. 16-17) discusses the importance of human capital in determining permanent income at some length, but mentions family structure as a determinant only in passing (p.55). 
Wright, the NJBSLI conducted the same types of annual surveys of working-class men and women employed in manufacturing enterprises across the state. Some details of the surveys changed from year to year, but certain core questions appeared in each survey: the city or town in which the respondent worked; the broad industry in which he worked (i.e., glass, iron, construction, etc.); a reasonably precise job title (i.e., green bottle glass blower, puddler, plasterer, etc.); the number of hours worked in a typical day; typical wages by day, week, or month, depending on the individual's pay cycle; the number of working days the individual was not employed due to sickness, an inability to find work, which usually implied scheduled seasonal factory shutdowns, and days missed for other reasons, most often a strike or other labor action; the number of individuals in the household; the worker's annual income from his or her job; any additional income aggregated up to annual figure earned by other household members employed outside the home; the household's total annual expenses, sometimes broken down into categories such as rent, food, clothing, and other expenses; and whether the household had accumulated any savings in the past year. Other questions included in some, but not all years, involved the ages of children in the household, whether the household took on debt during the year, or had saved in previous years.

Although the surveys provide details about work, income, and spending, New Jersey's labor bureau did not ask what now seem to be obvious questions. They did not ask about age, race, marital status, education, or job experience. In 1888 alone they inquired into the respondents' nativities, but the response rate was relatively low even when other parts of the survey were complete. It is likely that the bureau revisited some of the same enterprises in more than one year, but it is not possible to construct an individual-level panel because individuals are not identified by unique number across years. In 1884, a few different individuals were assigned the same number. These instances were identified in the second round of data cleaning and the income-spending-household size variables were accurately matched based on place and job identifiers. The five annual surveys yielded 3,650 individual records, but only 2,940 reported information on annual income and/or expenses that afford a calculation of household saving. Of these, age-at-decline was reported by the individual or could be imputed from Ransom and Sutch (1995) based on a 
respondent's industry/job title for just 1,143 individuals. Regressions reported below report results for the full sample and the age-at-decline subsample.

Despite the absence of information on age, job tenure, and other individual characteristics, the surveys provide valuable documentation of working-class saving behaviors that have been long neglected (Carter and Ransom 1991). Similar surveys conducted in other states between the 1870s and the 1910s have been used to investigate retirement, asset accumulation, and job tenure (see Carter et al (1991) for a brief survey). And using the New Jersey surveys Averett et al (2005) find that workers received a partially compensating wage differential for anticipated seasonal unemployment.

\subsection{A note on theory and measurement}

One concern with using income and expenditure to estimate saving rates is that modern approaches do not define current saving as current income less expenditure. Although there are differences, most approaches define annual saving as changes in net wealth, which includes changes in cash holdings and durable goods, including housing, which provide a flow of future services. Changes in net wealth, which equals current saving, are approximately the difference between disposable income less expenditure on perishable goods and current services.

Because the New Jersey surveys contain no information on wealth or expenditures on durables, the saving rate is measured as the difference between household income less expenditure all divided by household income (e.g., saving rate $=($ total income - total expenditure $) /$ total income $)$. The income-less-expenditure measure provides a lower bound estimate of the saving rate because some reported expenditures qualify as saving.

It is possible, however, to generate alternative estimates of saving rates that account for some saving, namely insurance premiums and house payments, from responses to the 1882, 1883, and 1886 surveys. The 1886 survey, for instance, inquired into life insurance payments and sickness society dues (see Bodenhorn 2018 for details), which average about $\$ 11.10$ per household per year. If these values are counted as expenditures rather than saving, calculated saving rates will be below actual rates. To correct for the underestimate caused by including premiums and 
dues as current expenditure, data on premiums and dues in the 1886 report was used to predict premiums paid in other years using household size, occupational skill category, and county and industry fixed effects as predictors. The (untabulated) predicted values were used to generate revised saving rates by subtracting insurance expenditures from current expenditures and income.

A second adjustment involves estimating saving in the form of investment in owner-occupied housing. Home ownership is both a current consumption good and an investment good, but it is difficult to empirically extract the consumption and saving components from the data. One way to deal with the problem of accounting for housing services is to eliminate housing expenditures (whether rent or house payments) from both expenditures and income (Attanasio et al 2005), which mitigates the problem if the current consumption component is large. Some respondents to the 1883, 1884, and 1886 surveys provide the annual dollar value of rent paid (average of $\$ 114$ /year); other households did not report a value for house rent. In 1886, the survey notes that most nonrenters owned their homes. If all respondents who returned no value for rent in the 1883 through 1886 surveys lived in owner-occupied housing it implies an ownership rate of $58.1 \%$, which is well above the 34.3\% reported in the 1900 federal census (Census Bureau 2017). It is likely that some renters failed to report, but there is no way to distinguish between non-reporters and home owners. Additionally, if we assume that rent payments depends on family size, occupational skill category, and county and industry fixed effects, the current consumption component of housing can be predicted for the years 1883 to 1886 for respondents not reporting a value for rent. Untabulated regressions predict an average rental value of owner-occupied house is $\$ 96.53$, compared to average annual rent for rental units of $\$ 114.63$.

The insurance and current rental value of housing adjustments imply a calculated saving rate equal to [(total income - (total expenditure - estimated insurance premiums - estimated rental expenditures) / (total income - estimated rental expenditures)]. To better understand the mechanics and implications of the insurance and rental adjustments consider the case of survey respondent number 124 in the 1886 report (selected at random from those reporting neither premiums nor rent). He worked as a skilled machinist in an iron foundry in Florence, Burlington 
County, New Jersey. He reported $\$ 600$ in earnings, $\$ 501$ in current expenditures, but $\$ 0$ in premiums and rent. The saving rate calculated as income - expenditure yields a saving rate of $16.5 \%$. Using the predicted value of $\$ 131.63$ for annual rent and $\$ 5$ for insurance premiums, however, the estimated saving rate is $22.2 \%$. Similar comparisons of current and predicted saving rates can be estimated for 1,529 of the 2,940 respondents; the average current income-current expenditure saving rate for these households is $8.5 \%$ and the average predicted premium-rent adjusted saving rate is $12.8 \%$. Appendix Figure A1 provides a plot of the current versus the estimated saving rate. Although the simpler calculation underestimates the saving rate, the correlation coefficient between the two series is 0.98 ( $\mathrm{p}$-value <0.001). Given the high correlation between the two series and that the current incomecurrent expenditure sample is nearly twice the size, the subsequent analyses use the larger current income-current expenditure sample

$<$ Table 1 about here $>$

\subsection{Data description and summary statistics}

Table 1 provides summary statistics for the main sample of 2,940 observations and two subsamples used in later analyses. The surveys provide a valuable perspective on workingmen's condition in the late nineteenth century. Most of the state's counties appear in the sample, though the industrial regions of Camden-Gloucester counties (proximate to Philadelphia) and Passaic-Essex-Hudson counties (proximate to New York City) are overrepresented. The samples also provide information on workers in a broad array of industries, though the glass making industry, which specialized in green glass bottles and window/plate glass make up nearly one-fourth of the sample. Nearly half of the surveyed workers are classified as semi-skilled operatives. One-third is relatively unskilled laborers. Less than $2 \%$ are clerical workers employed by industrial enterprises. And approximately one-seventh is skilled or craft workers. The 1884 survey provided more than onethird of the observations; the 1888 survey provided one-fifth. Worker families were relatively large. Nearly two-thirds of the respondents resided in households with five 
or more residents. Women represent just $2 \%$ of the sample respondents and were employed mostly in textiles mills and shoemaking establishments.

The first question then is whether nineteenth-century working-class households had the wherewithal to save. And if so, did they? Average reported income in the full sample is $\$ 590.82 .^{5}$ Reported earnings are consistent with estimates of GDP per worker derived from available national income accounts: $\$ 686.30$ in 1880 and $\$ 617.57$ in 1890 (Carter et al 2006, Series Ca9-19, Ba1-10, Ba4049). Average reported total household expenses are $\$ 588.80$. Average estimated household saving, calculated as the difference between reported income and expenses is $\$ 78.57$.

\section{Figure 1}

Household saving rate by income percentile

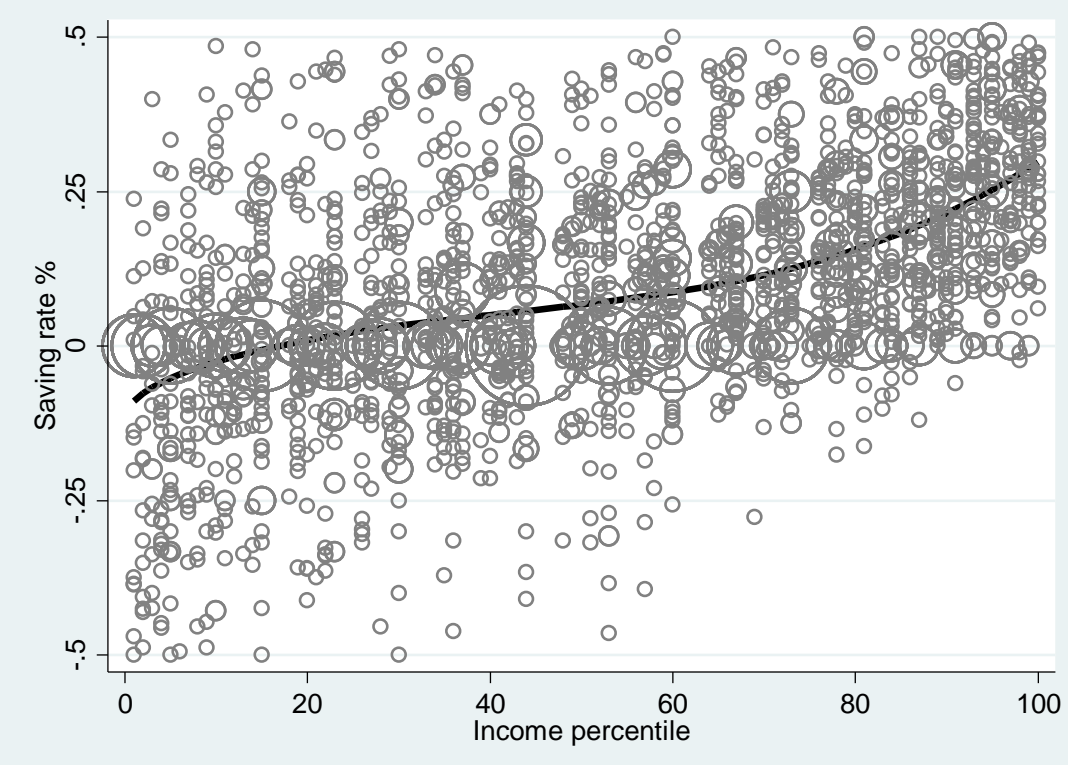

Source: author's calculations from data in NJBSLI (1883-1888).

Notes: Circle size reflects relative number of observations for each saving rate-income percentile pair. Dark line is fitted third degree polynomial with no additional correlates.

\footnotetext{
${ }^{5}$ In 2015 dollars, the $\$ 590$ value lies between $\$ 15,000$ and $\$ 89,000$. The lower value is based on the CPI; the higher value is based on comparisons of labor costs across time (https://www.measuringworth.com/uscompare/, accessed December 2016). The late nineteenthcentury value is in line with an average US manufacturing sector wage of $\$ 35,000$ in 2015 (http://www.worldsalaries.org/usa.shtml).
} 
Deaton (1991, 1992) argues that reliable individual-level saving data from developing countries exhibit three characteristics: (1) zero saving is common, consistent with consumer impatience; (2) dissaving is common; and (3) saving rates increase with income. Figure 1 presents a Brady-Friedman (1947) graph of household saving rates (saving/income) plotted against the households' place in the income distribution reported as percentiles. Each saving rate-income percentile pair is weighted by the fraction of observations for that pair. A third-degree polynomial estimated without additional correlates is overlaid to illustrate the central tendency. Several notable features of the figure stand out. First, approximately one-third of households report annual incomes equal to annual expenditures, implying impatience and zero saving. Second, households at all points in the income distribution reported income in excess of expenditures, which implies that even households at the bottom of the income distribution saved, probably in anticipation of future emergencies or retirement. Nevertheless, the proportion of households in the lower quintile of incomes that saved was lower than in the middle quintiles. When working poor households realized a surplus, they banked it.

A third feature of the scatterplot is that households at all points in the income distribution dissaved, though the proportion of dissavers in the highest quintile is small. Relatively large dissaving rates for some households point to a reliance on past saving or, perhaps, charity. Among households in the first income quintile, the mean saving rate was $-2.72 \%$ and only $18.5 \%$ of households reported saving in the past year, but $31.4 \%$ reported having saved in previous years. That nearly one-third of low-income households had previously saved suggests some kind of forward-looking, precautionary saving behavior. Fourth, the estimated relationship between income percentile and saving rate, not controlling for other factors, suggests that the typical household at each percentile of the income distribution above the twentieth percentile engaged in net saving and the typical saving rate for households in the tenth decile approached 25\%.

More 53\% of respondents reported household income in excess of expenditure at rates consistent with other sources (Alter et al 1994; Sutch 2011), but the issue remains whether households actually saved. The 1883 through 1885 surveys offer one validity check. These three surveys asked a simple question: "Have you 
accumulated any savings during the past year?" The responses were coded 0 (no) or 1 (yes). Approximately 40\% reported saving in the past year. Pearson correlation coefficients between saving in the past year and the constructed retrospective saving rate used in Figure 2 is 0.62 ( $\mathrm{p}$-value $<0.001$ ). It is reasonable to conclude that households that reported income in excess of expenditures saved some part of the estimated surplus.

Figure 2

Household saving rate by household head reported days lost less industryworker average days lost

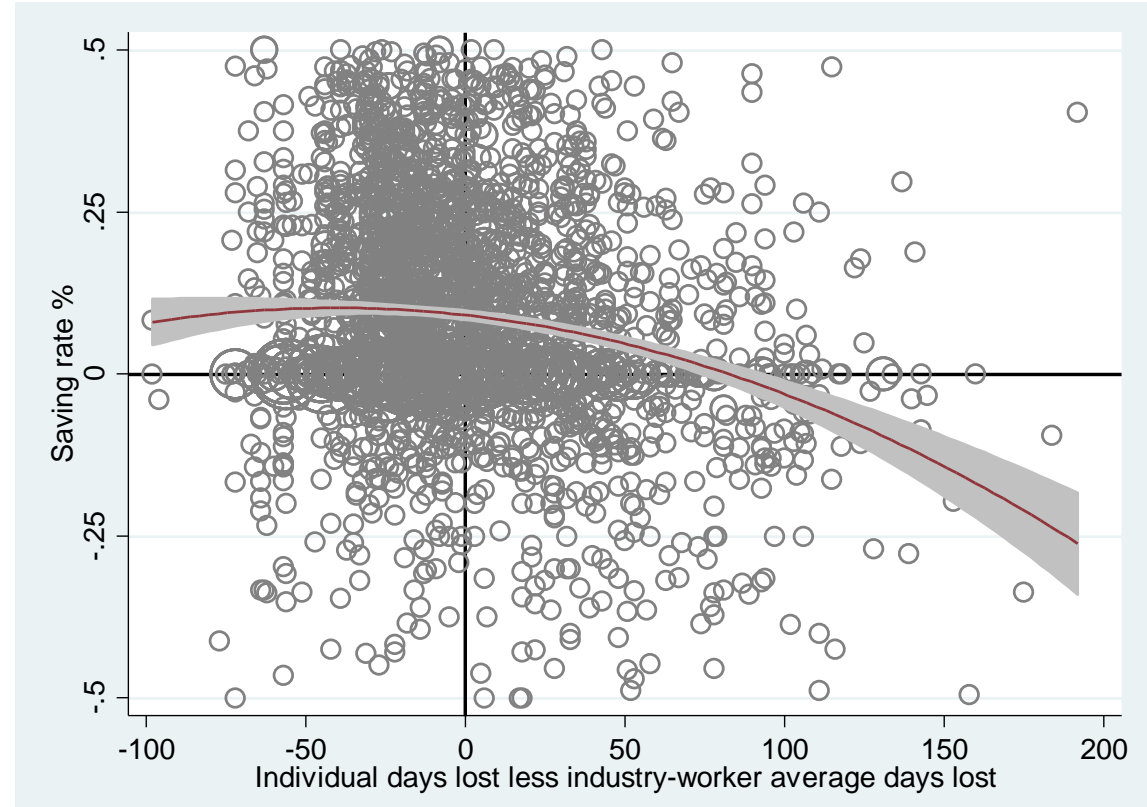

Sources: author's calculations from data in NJBSLI (1883-1888).

A second concern is whether the data reveal enough about transitory income factors to make a test of the permanent income hypothesis possible. Table 2 presents two matrices that report negative, zero, and positive savings in columns and whether the respondent experienced a positive (more days than anticipated) or negative (less days than anticipated) deviation from average days lost. Panel A uses the establishment-level estimates of days lost; Panel B uses the average of the worker- 
reported days lost as the baseline from which deviations are calculated. ${ }^{6}$ The permanent income hypothesis predicts that most of the observations will be in the upper left and lower right cells. In Panel A, 50.4\% of observations appear in these cells; and, if the negative and zero saving cells are collapsed into nonpositive saving, the diagonal contains $59.6 \%$ of observations. In Panel B, $43.9 \%$ of households appear in the upper left-lower right cells; and 55.5\% appear in the diagonal of nonpositive-positive matrix.

Friedman (1957, p. 57) offers another approach to determine if there is sufficient variance in transitory income to uncover whether households were permanent income savers. He shows that one minus the elasticity of measured consumption to measured income (i.e., $\left.1-\left(\partial \mathrm{C}_{\mathrm{t}} / \partial \mathrm{Y}_{\mathrm{t}}\right) *\left(\mathrm{Y}_{\mathrm{t}} / \mathrm{C}_{\mathrm{t}}\right)\right)$ equals the percent of the variance of measured income attributable to the transitory factors. In the midtwentieth-century United States and United Kingdom, the elasticities derived from large nationally representative budget surveys were $13 \%$ for the UK and $18 \%$ for the US. It is well documented that industrial employment was less stable and less predictable in the late-nineteenth century than in the twentieth and that it varied considerably across industries (Atack et al 2002; Averett et al 2005).

Untabulated OLS regressions of the natural log of household expenditure on the natural log of income generate generally larger estimates of the percent of measured income attributable to transitory components than the values observed in the twentieth century. The income elasticity of expenditure for New Jersey households in which the head was employed in textiles was 0.98 , which implies that $2 \%$ of the variance of measured income is attributable to transitory factors. In shoes the elasticity is 0.97 , but in construction and primary metals it is just 0.74 . In glass industry it is 0.52 . If these values are taken at face value, the percentage of the variance in measured income attributable to transitory factors is potentially twice as high for households whose principal breadwinner is employed in some latenineteenth New Jersey industries as for the average mid-twentieth century US household. Due to small sample sizes for some industries, the estimates should be treated with care, but even if the true income elasticities are greater than the

6 Zero deviations in days lost is not included because there were only five households that experienced the establishment average and 68 that experienced the worker-by-industry average. 
estimates, they still point to the importance of saving for most nineteenth-century working-class households. Given the extent to which transitory unemployment weighed heavily on historical incomes, it is informative to understand how household saving behaviors responded to unanticipated unemployment.

\section{Results}

\subsection{Reduced-form estimates}

\section{Table 2}

\begin{tabular}{|c|c|c|c|c|c|c|}
\hline \multicolumn{7}{|c|}{ Reduced-form income and saving equations } \\
\hline \multirow[b]{2}{*}{ VARIABLES } & (1) & $(2)$ & (3) & (4) & $(5)$ & $(6)$ \\
\hline & Income & Saving & Income & Saving & Est Income & Est Saving \\
\hline \multirow[t]{2}{*}{ Days lost } & $-1.482^{* *}$ & $-0.789 * *$ & $-1.543^{* *}$ & $-0.758^{* *}$ & $-2.134 * *$ & $-1.385^{* *}$ \\
\hline & {$[0.280]$} & [0.189] & {$[0.259]$} & {$[0.165]$} & [0.490] & {$[0.384]$} \\
\hline \multirow[t]{2}{*}{ Days lost sq } & $0.002 * *$ & $0.001 * *$ & $0.002 * *$ & $0.001 * *$ & $-0.001+$ & $-0.002 * *$ \\
\hline & {$[0.000]$} & {$[0.000]$} & {$[0.000]$} & {$[0.000]$} & {$[0.001]$} & {$[0.000]$} \\
\hline \multirow[t]{2}{*}{ Operative } & $170.103^{*}$ & $60.454+$ & $167.968 *$ & $58.757+$ & $256.003^{*}$ & 119.015 \\
\hline & [59.381] & [30.799] & [60.528] & [31.127] & [102.542] & [71.524] \\
\hline \multirow[t]{2}{*}{ Craft } & $185.931 * *$ & $58.390^{* *}$ & $176.648^{* *}$ & $53.173^{* *}$ & $240.218^{* *}$ & $82.872^{*}$ \\
\hline & [23.932] & [12.224] & [23.874] & [11.617] & [41.752] & [27.510] \\
\hline \multirow[t]{2}{*}{ Other skill } & $109.468^{*}$ & $52.524^{*}$ & $98.720^{*}$ & $53.034^{*}$ & $109.102 *$ & 36.731 \\
\hline & [36.583] & [21.523] & [35.033] & [23.573] & [42.075] & [58.834] \\
\hline Observations & 2,940 & 2,940 & 2,878 & 2,878 & 1,523 & 1,523 \\
\hline \multicolumn{2}{|l|}{ Test 1} & 0.287 & & 0.174 & & 0.338 \\
\hline \multicolumn{2}{|l|}{ Test 2} & 0.000 & & 0.000 & & 0.000 \\
\hline \multicolumn{2}{|l|}{ Test 3} & 0.002 & & 0.003 & & 0.001 \\
\hline \multicolumn{7}{|c|}{$\begin{array}{l}\text { Notes: standard errors clustered on industry of employment in brackets. } * \text { implies p-value }<0.05 ; * * \text { implies } \mathrm{p}- \\
\text { value }<0.01 . \text { Days lost in Column }(1-2 \text { and } 5-6) \text { is difference between individual report and mean of individual reports; } \\
\text { Columns (3-4), it is the difference between individual report and mean enterprise report for slack days and } 5 \% \text { of days } \\
\text { due to sickness. Test } 1: \text { p-value of Days lost variable }=-1 \text {; Test } 2: \text { p-value of effect of days lost on income equal effect } \\
\text { of days lost on saving; Test 3: skill variables jointly insignificant. The regressions include the full set of controls, } \\
\text { including county of resident, industry of employment, family size, proximity to a formal financial institution, and year } \\
\text { fixed effects. } \\
\text { Sources: Author's calculation from NJBSLI (1883-1888). }\end{array}$} \\
\hline
\end{tabular}

Coefficient estimates for the principal transitory and permanent income variables from reduced-form income and saving equations are reported in Table 2 (the full set of estimates is reported in Appendix Table 2A). Columns (1) and (2) use 
the base sample, which uses worker-reported annual income/expenses; the days lost variables are defined as the difference between self-reported days lost and an industry-year specific average number of days lost by all workers and its square. A one standard-deviation increase in the difference in days lost reduces income by $\$ 54.06$, or by about $9.2 \%$ of mean reported income. The transitory component of worker income represents a potentially large share of late nineteenth-century workers' incomes. Semi-skilled operatives, skilled craft workers, and clerical workers earn more than laborers, which captures, in part, the permanent income effect of earlier human capital investments.

The days lost variables are individually and jointly different from zero in the saving equation (Column 2). But a test of the permanent income hypothesis is whether all positive transitory income realizations are saved (or negative transitory shocks dissaved), which - given the definition of the transitory variable - implies that the coefficient on Days lost is significantly different from -1 . The p-value, reported as Test 1 , reveals that the null cannot be rejected. The implication is that most of the reduced income arising from transitory factors is dissaved rather than not consumed, a result that provides support for a strong version of the permanent income hypothesis.

A second implication of the strong version of the permanent income hypothesis is that effect of transitory factors should be the same in the income and saving equation, which is not the case. An additional lost day of work reduces income by an estimated $\$ 1.48$ (compared to mean reported daily wage for those reporting of $\$ 2.55[\mathrm{sd}=1.26])$, but reduces saving by $\$ 0.79$. Test 2 reports the $\mathrm{p}$-value of the joint test of coefficient equality on days lost and its square in the two equations. The null hypothesis of coefficient equality is rejected. This result provides limited support for a direct implication of the hypothesis, but it is consistent with the overriding argument of both the permanent income/life cycle and buffer stock approaches that households tend to smooth consumption over their lifetimes, and that a household will save out of positive transitory realizations to tide it over a negative realization. These results reveal that dissaving was a fraction of diminished income. 
Although the results are generally consistent with a strong version of the permanent income hypothesis, they are not necessarily consistent with a third of the theory's implications, namely that all permanent income is consumed ( $\beta_{\mathrm{p}}=0$ in Eq. (10)). Of the variables available from the surveys, the skill variables are those most likely to capture the most relevant factor (human capital) affecting the workers' permanent income, given that less than one-third (probably much less) of workers owned real estate or other immobile capital. ${ }^{7}$ The analog to the implication that all permanent income is consumed is that the coefficients on the skill categories should be equal to zero in the reduced-form saving equation. Craft and clerical workers saved substantially more than laborers. The coefficient on Operatives is larger than that for laborers, but it is barely significant at conventional levels. It should be noted, however, that the coefficients on the skill category variables in the saving equation are one-third to one-half the magnitude of the coefficients in the income equation. If we interpret these ratios as a marginal propensity to save from permanent income among nineteenth-century workers, the estimated propensity to save from permanent income is notably smaller than the propensity to save from transitory income. It is important to reiterate, however, that because there is no information about workers' assets, it is difficult to interpret any of the coefficients from the regressions as capturing a genuine permanent income component. But if any of available set of the variables is likely to do so, it is the set of skill categories.

Columns (3) and (4) report reduced-form estimates using an alternative measure of the days lost variable. Average lost days is calculated from enterprise reports of slack days and assumes that the average worker loses $5 \%$ of time to illness. Instead of reported annual income, Columns (5) and (6) use incomes estimated from the product of daily wages and days worked. The results are robust to alternative definitions. The data fail to reject the null hypothesis that the propensity to save from transitory income is one (Test 1). Additionally, the propensity to save from

7 In the 1883, 1884, and 1886 surveys, workers provided information on annual expenditures for rent, clothing, food, and so forth. In these years, $69.8 \%$ of respondents reported paying rent, the remaining respondents did not provide a value. In some instances, but neither all nor even most, a notation was made that the worker owned his or her residence. The notation appeared in so few responses that this information was not entered into the data set. 
nontransitory income is about one-third to one-half the propensity to consume from transitory income.

\subsection{Two-step estimates}

Two-step estimates provide a test of the implications of the structural saving model (Equation [6]). The two-step method is implemented by first estimating by OLS the reduced-form income equation (Equation [10]). Estimates of transitory and permanent income are then estimated from the OLS coefficients. Household saving is then regressed on the resulting estimates of permanent $\left(\mathrm{Y}_{\mathrm{j} j \mathrm{irt}}\right)$ and transitory $\left(\mathrm{Yt}_{\mathrm{jirt}}\right)$ incomes. The regressions also include the residual income $\left(\mathrm{Ye}_{\mathrm{j} i r t}\right)$. The second-stage equation is then estimated jointly with the original reduced-form income equation to correct for correlated errors in the two equations (Barro 1977). Because residual income is the mean of the errors from the first step it contains both permanent and transitory components and cannot be interpreted as transitory; it is unexplained income. The permanent income hypothesis implies that the coefficient on the residual should fall between the permanent and transitory coefficients, though measurement error will bias the coefficient on unexplained income upward toward one (Paxson 1996).

Before discussing the coefficients, Panel A of Table 3 reports estimates of the levels of permanent and transitory incomes as a check on the credibility of the procedure. Three estimates are provided using the same samples as in Section 4.1. In each instance, estimated permanent income exceeds actual reported income. In Column (1), for instance, which uses the reported income / reported days lost sample, estimated permanent income is $\$ 606.34$ compared to average reported income of $\$ 590.82$. The difference equals the estimate of transitory income, a result that necessarily follows from the statistical procedure, but one also consistent with

the permanent income hypothesis. Transitory income is, by definition, the difference between a household's (expected) permanent and current realized income. The expected value of residual income is zero, which follows from the estimation procedure, but residual income shows substantial variance. 


\begin{tabular}{|c|c|c|c|}
\hline \multicolumn{4}{|c|}{ Table 3} \\
\hline \multicolumn{4}{|c|}{ Two-step estimates } \\
\hline & (1) & (2) & (3) \\
\hline VARIABLES & Saving & Saving & Est saving \\
\hline \multicolumn{4}{|c|}{$\underline{\text { Panel A }}$} \\
\hline \multicolumn{4}{|c|}{ First-stage estimates, mean (sd) } \\
\hline \multirow[t]{2}{*}{ Y(permanent) } & 606.339 & 581.861 & 668.974 \\
\hline & [164.421] & [251.699] & [332.469] \\
\hline \multirow{2}{*}{ Y(transitory) } & -15.522 & 11.827 & -32.425 \\
\hline & [56.324] & [64.810] & [131.934] \\
\hline \multirow[t]{3}{*}{ Y(residual) } & 0.000 & 0.000 & 0.000 \\
\hline & [183.110] & [182.439] & [317.695] \\
\hline & $\underline{\text { Panel B }}$ & & \\
\hline \multirow[t]{2}{*}{ Y(permanent) } & $0.254^{* *}$ & $0.237^{* *}$ & $-0.127 * *$ \\
\hline & {$[0.015]$} & {$[0.016]$} & {$[0.020]$} \\
\hline \multirow[t]{2}{*}{ Y(transitory) } & $0.454^{* *}$ & $0.437 * *$ & $0.687^{* *}$ \\
\hline & {$[0.036]$} & {$[0.032]$} & {$[0.034]$} \\
\hline \multirow[t]{2}{*}{$\mathrm{Y}$ (residual) } & $0.412^{* *}$ & $0.415^{* *}$ & $0.719 * *$ \\
\hline & [0.011] & {$[0.011]$} & {$[0.019]$} \\
\hline \multirow[t]{2}{*}{ Slack day sigma-sq } & 0.332 & 0.224 & $6.296^{* *}$ \\
\hline & {$[0.247]$} & {$[0.244]$} & {$[0.444]$} \\
\hline \multirow[t]{2}{*}{ Constant } & $-60.551 * *$ & $-53.841 * *$ & 26.584 \\
\hline & [9.985] & {$[10.270]$} & [18.546] \\
\hline Observations & 2,878 & 2,878 & 1,497 \\
\hline R-squared & 0.433 & 0.434 & 0.767 \\
\hline Test $Y(t)=1$ & 0.000 & 0.000 & 0.000 \\
\hline Test $Y(t)=Y(p)$ & 0.000 & 0.000 & 0.000 \\
\hline \multicolumn{4}{|c|}{$\begin{array}{l}\text { Notes: standard errors clustered on industry of employment in } \\
\text { brackets. } * \text { implies p-value }<0.05 ; * * \text { implies p-value }<0.01 . \\
\text { Sources: author's calculation from NJBSLI }(1883-1888) .\end{array}$} \\
\hline
\end{tabular}

Panel B reports coefficient estimates from the three models. The coefficients are not consistent with a strong version of the permanent income hypothesis: we can reject the null hypothesis that the coefficients on permanent income are zero, and the null that the coefficient on estimated transitory income is one. But like the results in Section 4.1, the coefficients on transitory income are between 1.8 and 5.4 the magnitude of the (absolute value) of permanent income coefficients and the null 
hypothesis of coefficient equality is rejected in each case. Thus, the propensity to save from transitory income is notably larger than the propensity to save from estimated permanent income.

An additional feature of the results is that the proxy measure used to capture the effect of income variance on saving is about the same size as the coefficient on permanent income, but is statistically insignificant in two cases. A positive coefficient implies that a household with higher variance of income saves more, a plausible result, and one consistent with constant absolute risk aversion. But a zero coefficient is consistent with a utility function quadratic in risk (Paxson 1996), and we cannot reject the null hypothesis of no effect in two cases using reported income and expenditures. It should be kept in mind, however, that variance of slack days is derived from three years of establishment-level data and does not vary across households or over time. There may be other sources of unobserved variation that influence saving differently, but the results are consistent with the buffer-stock hypothesis. Households that experience more variable incomes will save more when realized income exceeds expected income as insurance against periods of negative realizations.

\subsection{Maximum likelihood simultaneous estimation}

Maximum likelihood estimates are used to test the overidentifying restrictions suggested by Equations (9) and (10). The full model estimates imply 46 restrictions, but the restrictions can be separated into four groups: the transitory variables (days lost deviations) alone; the permanent variables (skill levels) alone; the combination of transitory and permanent variables; and all variables. The overidentifying restrictions on the transitory variables are that the coefficients in the saving equations are proportional to the coefficient on transitory income reported in Table $3\left(\alpha_{2}\right)$. Similarly, the restrictions on the permanent variables are proportionality equal to $\alpha_{1}$. There is no implied proportionality restriction on the neighborhood and family structure variables, so the test proceeds under the assumption that coefficient of proportionality is one. 


\section{Table 4}

Overidentification tests -- maximum likelihood joint estimate models

Overid test

Income

Estimated days lost

$\begin{array}{lccc}\text { Transitory variables } & 5.28 & 3.07 & 25.76 \\ \chi \text {-sq (2) } & {[0.071]} & {[0.22]} & {[0.000]} \\ & & & \\ \text { Permanent variables } & 19.48 & 20.66 & 38.86 \\ \chi \text {-sq (3) } & {[0.00]} & {[0.00]} & {[0.00]} \\ & & & \\ \text { Trans \& Perm } & 23.12 & 22.57 & 258.53 \\ \chi \text {-sq (5) } & {[0.00]} & {[0.00]} & {[0.00]} \\ & & & 648.02 \\ \text { All variables } & 957.62 & 929.4 & {[0.00]} \\ \chi \text {-sq (46) } & {[0.00]} & & \\ & & & \\ \text { Notes: the values in brackets are p-values. The underlying coefficients are reported in Table } \\ \text { 2 and Appendix Table A2. }\end{array}$

Table 4 reports the overidentification test statistics and their p-values. The test statistics on the permanent income variables, the joint transitory and permanent variables, and the full set of variables imply that the restrictions can be rejected, but in two of the three tests on the transitory income variables the restrictions cannot be rejected. Thus, tests based on reported income point toward behaviors consistent with one of the important implications of the permanent income hypothesis. Shocks to transitory income translate into proportionate changes in household saving.

\subsection{Occupational prestige index and age-at-decline samples}

Table 5 reports the second-stage results from the two-step procedure using Reiss's (1961) occupational prestige score to measure human capital as the principal determinant of permanent income. Reiss's index ranges between zero and 100. The values in the New Jersey sample range between zero (rag picker, street sweeper, or sand digger) to 79 (manager of a glass establishment) with an average of 16.53 (sd = 10.82), or the equivalent of a blacksmith, a house painter, or a ship carpenter. 


\begin{tabular}{|c|c|c|}
\hline \multicolumn{3}{|c|}{ Table 5} \\
\hline \multicolumn{3}{|c|}{ Two-step estimates and MLE overidentification tests } \\
\hline & (1) & (2) \\
\hline \multirow[t]{3}{*}{ VARIABLES } & Saving & Saving \\
\hline & Occupation prestige & Age-at- \\
\hline & Index & decline \\
\hline \multirow[t]{2}{*}{$\mathrm{Y}(\mathrm{p})$} & $0.259 * *$ & $0.336^{* *}$ \\
\hline & {$[0.015]$} & {$[0.024]$} \\
\hline \multirow[t]{2}{*}{$Y(t)$} & $0.447 * *$ & $0.390^{* *}$ \\
\hline & {$[0.037]$} & {$[0.041]$} \\
\hline \multirow[t]{2}{*}{$\mathrm{Y}(\mathrm{e})$} & $0.407 * *$ & $0.459^{* *}$ \\
\hline & {$[0.011]$} & {$[0.021]$} \\
\hline \multirow[t]{2}{*}{ Slack day sigma-sq } & 0.292 & 0.392 \\
\hline & {$[0.248]$} & {$[0.591]$} \\
\hline \multirow[t]{2}{*}{ Constant } & $-64.988 * *$ & $-108.132^{* *}$ \\
\hline & {$[9.988]$} & [18.615] \\
\hline Observations & 2,878 & 1,121 \\
\hline R-squared & 0.430 & 0.493 \\
\hline Test $Y(t)=1$ & 0.000 & 0.000 \\
\hline Test $\mathrm{Y}(\mathrm{t})=\mathrm{Y}(\mathrm{p})$ & 0.000 & 0.241 \\
\hline \multicolumn{3}{|l|}{ Overid tests - $\mathrm{p}$-values } \\
\hline Transitory only - $\chi$-sq(2) & 0.042 & 0.002 \\
\hline Permanent only - $\chi$-sq(10) & 0.000 & 0.000 \\
\hline All variables $-\chi$-sq(49) & 0.000 & 0.000 \\
\hline \multicolumn{3}{|l|}{ Notes: see Table 3} \\
\hline Sources: see Table 3 & & \\
\hline
\end{tabular}

Coefficient estimates in Column (1), which uses the full sample of 2,878 observations and the alternative human capital measure, generates estimates similar to those reported in Table 2. The coefficient on transitory income is less than unity, but it is $72 \%$ larger than the coefficient on nontransitory income. And the null hypothesis of coefficient equality is easily rejected. Workers save more when they employed in industries in which the variance of slack days increases, though the 
effect is not precisely estimated. The $\chi$-squared statistics reported at the bottom of the table test whether the coefficient of proportionality implied by relationship between the income and saving equation holds. We can reject the null that the proportionality condition on the transitory variables holds at the $5 \%$ level, but not at the $1 \%$ level. The other proportionality conditions, however, are rejected. Using an alternative human capital measure does not change the conclusions generated above.

Column (2) of Table 5 reports the results from a subsample of 1,121 workers who reported an age-at-decline or worked in an occupation in which age-at-decline could be imputed using the ages reported in Ransom and Sutch (1995). The smaller sample yields results less consistent with the permanent income hypothesis. The null hypothesis that the fraction of transitory income saved equals one is rejected. The null hypothesis that the fraction of transitory and permanent income saved is equal cannot be rejected. The proportionality conditions are also rejected.

The results from the age-at-decline sample are a seemingly consequence of using the smaller sample rather than adding age-at-decline as a determinant of nontransitory income. When the model is estimated using the age-at-decline sample without the age-at-decline variables, the coefficient estimates are approximately the same as those reported in Column (2), as are the results of the statistical tests.

\section{Conclusions}

Saving is essential to the health of economies and households, yet relatively little scholarship investigates savings among the urban working class in the late nineteenth century. This paper uses five surveys of industrial workers in 1880s New Jersey. An analysis of data generated by New Jersey's surveys of late nineteenthcentury workers provides unprecedented insights into the saving behaviors of the era's working-class households. Although the results are not fully consistent with strong versions of Friedman's (1957) permanent income hypothesis, they show that propensities to save out of transitory income are rather high. The reduced-form and maximum likelihood estimates imply that about three-fourths of transitory income is saved; two-step estimates imply fractions of about one-half. The result is important because it indicates that households saved and dissaved out of transitory income such that the consumption effects of transitory income shocks were spread over 
time. Past savings are used to buffer negative shocks due to layoffs or illness. And positive shocks to current income are saved in anticipation of future negative realizations. These results may provide some insights into how households responded to transitory shocks from factors other than lost work days, but the marginal propensity to save from nontransitory income was generally positive, which may point toward a limited capacity to tap credit markets to see households through tough times.

Other states conducted comparable surveys in the same period, some of which inquired into household incomes and savings. The techniques used here might be usefully employed in the analysis of those surveys to determine whether the New Jersey results can be generalized. In the meantime, the results generated here point toward households that made use of an expanding array of formal savings options to smooth consumption over time. One component of the NJBSLI's annual worker surveys was an open-ended question about the principal concerns of working-class households. The majority of the responses focused on the evils of alcohol abuse and child labor, too-low wages for too-hard work, and the need for universal education. Some workers, however, focused on the importance of savings, or economy in contemporary parlance. A rolling mill employee argued that for his fellows to avoid poverty "they should practice more economy" (NJBSLI 1883, 114). A machinist responded that "economy and laying up for a rainy day are necessary for a man to make his way in the world," while another wrote "economy is the only hope of the poor man." And in a statement reminiscent of those encouraging young professionals in the twenty-first century to contribute to their $401(\mathrm{k})$ accounts early and often, one nineteenth-century worker observed that "the most rigid economy should be observed, until he can get a start in life; then it will be easier" (NJBSLI 1883, 122). Nineteenth-century working men and women understood that saving was essential to their well-being. The evidence presented here points toward behaviors consistent with their understanding. 


\section{References}

Alter, George, Claudia Goldin, and Elyce Rotella. 1994. "The savings of ordinary Americans: the Philadelphia Saving Fund Society in the mid-nineteenth century." Journal of Economic History 54(4): 735-767.

Atack, Jeremy, Fred Bateman and Robert A. Margo. 2002. "Part-year operation in nineteenth-century American manufacturing: evidence from the 1870 and 1880 censuses." Journal of Economic History 62(3): 792-809.

Attanasio, Orazio P., Laura Blow, Robert Hamilton, and Andrew Leicester. 2005. Booms and busts: consumption, house prices, and expectations. Institute for Fiscal Studies working paper WP05/24.

Averett, Susan, Howard Bodenhorn, and Justus Staisiunas. 2005. "Unemployment risk and compensating differentials in late-nineteenth-century New Jersey manufacturing." Economic Inquiry 43(4): 734-749.

Barro, Robert. 1977. "Unanticipated money, growth and unemployment in the United States." American Economic Review 67(1): 101-115.

Beecher, Henry Ward. 1877. "Plymouth pulpit: sermon by Henry Ward Beecher." Christian Union 16(5) (August 1), 92.

Brady, Dorothy S. and Rose D. Friedman. 1947. "Savings and the income distribution." In Studies in Income and Wealth Volume Ten, pp. 247-265. Conference on Research in Income and Wealth. New York: National Bureau of Economic Research.

Browning, Martin and Annamaria Lusardi. 1996. "Household saving: micro theories and micro facts." Journal of Economic Literature 34(4): 1797-1855.

Carroll, Christopher D. 1992. "The buffer-stock theory of saving: some macroeconomic evidence." Brookings Papers on Economic Activity 2( ): 61-135.

Carter, Susan et al. 2006. Historical Statistics of the United States, Millennial Edition. New York: Cambridge University Press.

Carter, Susan B., Roger L. Ransom, and Richard Sutch. 1991. "The historical labor statistics project at the University of California.” Historical Statistics 24(2): 5265.

Deaton, Angus S. 1991. "Saving and liquidity constraints." Econometrica 59(5): 122148. 
Deaton, Angus S. 1992. "Household saving in LDCs" credit markets, insurance and welfare." Scandinavian Journal of Economics 94(2): 253-73.

Deaton, Angus S. 2005. "Franco Modigliani and the life-cycle theory of consumption.” BNL Quarterly Review 58(233), 91-107.

Ehrenberg, Ronald G. and Robert S. Smith. 2008. Modern Labor Economics: Theory and Public Policy $10^{\text {th }}$ ed. Pearson/Addison Wesley.

Fishback, Price V. 1998. “Operations of 'unfettered' labor markets: exit and voice in American labor markets at the turn of the century." Journal of Economic Literature 36(2): 722-765.

Friedman, Milton. 1957. A Theory of the Consumption Function. Princeton, N. J.: Princeton University Press.

Gallman, Robert E. 1986. “The United States capital stock in the nineteenth century." In Long-Term Factors in American Economic Growth, pp. 165-214. Edited by Stanley L. Engerman and Robert E. Gallman. Chicago: University of Chicago Press.

Keynes, John M. 1936. The General Theory of Employment, Interest and Money. New York: Harcourt, Brace and Company.

Modigliani, Franco. 1986. "Life cycle, individual thrift, and the wealth of nations." American Economic Review 76(3): 297-313.

Murray, John E. 2007. Origins of American Health Insurance: A History of Industrial Sickness Funds. New Haven: Yale University Press.

New Jersey. 1883. Bureau of Statistics of Labor and Industries. Sixth Annual Report. Trenton, N.J.:

New Jersey. 1884. Bureau of Statistics of Labor and Industries. Seventh Annual Report. Trenton, N.J.:

New Jersey. 1885. Bureau of Statistics of Labor and Industries. Eighth Annual Report. Trenton, N.J.: John L. Murphy, State Printer.

New Jersey. 1886. Bureau of Statistics of Labor and Industries. Ninth Annual Report. Trenton, N.J.: John L. Murphy Publishing Co.

New Jersey. 1888. Bureau of Statistics of Labor and Industries. Eleventh Annual Report. Trenton, N.J.: 
New Jersey. 1882-1889. Department of State. Annual Statements of the Banks and Savings Institutions of the State of New Jersey. Trenton: John L. Murphy Publishing Company, State Printers.

North, Douglass. 1979. "Capital accumulation in life insurance between the Civil War and the investigation of 1905." In Men in Business: Essays on the Historical Role of the Entrepreneur, pp. 238-253. Edited by William Miller. Westport, Conn.: Greenwood Press.

Pagan, Adrian. 1984. "Econometric issues in the analysis of regressions with generated regressors.” International Economic Review 25(1): 221-247.

Paxson, Christina H. 1992. "Using weather variability to estimate the response of savings to transitory income in Thailand." American Economic Review 82(1): 15 33.

Ransom, Roger L. and Richard Sutch. 1995. "The impact of aging on the employment of men in American working-class communities at the end of the nineteenth century." In Aging in the Past: Demography, Society, and Old Age, pp, 303-327. Edited by David I. Kertzer and Peter Laslett. Berkeley: University of California Press.

Reiss, Albert J., with the collaboration of Otis Dudley Duncan, Paul K. Hatt, Cecil C. North. 1961. Occupations and Social Status. Glencoe, J.J.: Free Press.

Rossiter, Clinton. 1955. Conservatism in America. New York: Alfred A. Knopf.

Schoenfeld, Margaret H. 1925. "Trend of wage earners' savings in Philadelphia." Annals of the American Academy of Political and Social Science 121: 1-65.

Sutch, Richard. 2011. "Hard work, nonemployment, and the wealth-age profile: evidence of a life-cycle strategy in the United States during the nineteenth century." Paper presented at NBER-DAE Spring Program Meeting (March 2011). Available at https://www.rand.org/content/dam/rand/www/external/labor/seminars/a dp/pdfs/2010/sutch.pdf

United States. Census Bureau. 2017. Historical Census of Housing Tables. Https://www.census.gov/hhes/www/housing/census/historic/owner.html. 
Table 1

Summary statistics

\begin{tabular}{|c|c|c|c|}
\hline VARIABLES & $\begin{array}{c}(1) \\
\text { Base } \\
\text { Sample }\end{array}$ & $\begin{array}{c}(2) \\
\text { Estimated } \\
\text { Days lost }\end{array}$ & $\begin{array}{c}(3) \\
\text { Estimated } \\
\text { Income }\end{array}$ \\
\hline Income & $\begin{array}{c}590.816 \\
(251.673)\end{array}$ & $\begin{array}{c}593.689 \\
(251.699)\end{array}$ & $\begin{array}{c}639.211 \\
(420.624)\end{array}$ \\
\hline Expenses & $\begin{array}{c}588.800 \\
(207.100)\end{array}$ & $\begin{array}{c}590.721 \\
(206.930)\end{array}$ & $\begin{array}{c}611.204 \\
(209.982)\end{array}$ \\
\hline Saving & $\begin{array}{c}78.570 \\
(143.860)\end{array}$ & $\begin{array}{c}79.420 \\
(144.188)\end{array}$ & $\begin{array}{c}107.482 \\
(337.273)\end{array}$ \\
\hline Days lost & $\begin{array}{c}0.000 \\
(40.580)\end{array}$ & $\begin{array}{l}-13.626 \\
(44.922)\end{array}$ & $\begin{array}{c}0.698 \\
(41.069)\end{array}$ \\
\hline Days lost sq & $\begin{array}{c}1,646.189 \\
(11,697.676)\end{array}$ & $\begin{array}{c}2,203.001 \\
(11,649.347)\end{array}$ & $\begin{array}{c}1,686.009 \\
(15,986.125)\end{array}$ \\
\hline Bergen & $\begin{array}{c}0.012 \\
(0.108)\end{array}$ & $\begin{array}{c}0.012 \\
(0.110)\end{array}$ & $\begin{array}{c}0.005 \\
(0.068)\end{array}$ \\
\hline Burlington & $\begin{array}{c}0.034 \\
(0.180)\end{array}$ & $\begin{array}{c}0.034 \\
(0.181)\end{array}$ & $\begin{array}{c}0.011 \\
(0.105)\end{array}$ \\
\hline Camden & $\begin{array}{c}0.104 \\
(0.306)\end{array}$ & $\begin{array}{c}0.105 \\
(0.307)\end{array}$ & $\begin{array}{c}0.069 \\
(0.253)\end{array}$ \\
\hline Cumberland & $\begin{array}{c}0.165 \\
(0.371)\end{array}$ & $\begin{array}{c}0.166 \\
(0.372)\end{array}$ & $\begin{array}{c}0.173 \\
(0.379)\end{array}$ \\
\hline Essex & $\begin{array}{c}0.116 \\
(0.320)\end{array}$ & $\begin{array}{c}0.116 \\
(0.321)\end{array}$ & $\begin{array}{c}0.107 \\
(0.309)\end{array}$ \\
\hline Gloucester & $\begin{array}{c}0.095 \\
(0.293)\end{array}$ & $\begin{array}{c}0.095 \\
(0.294)\end{array}$ & $\begin{array}{c}0.143 \\
(0.350)\end{array}$ \\
\hline Hudson & $\begin{array}{c}0.072 \\
(0.259)\end{array}$ & $\begin{array}{c}0.072 \\
(0.258)\end{array}$ & $\begin{array}{c}0.085 \\
(0.279)\end{array}$ \\
\hline Hunterdon & $\begin{array}{c}0.032 \\
(0.176)\end{array}$ & $\begin{array}{c}0.032 \\
(0.175)\end{array}$ & $\begin{array}{c}0.035 \\
(0.185)\end{array}$ \\
\hline Mercer & $\begin{array}{c}0.024 \\
(0.152)\end{array}$ & $\begin{array}{c}0.024 \\
(0.154)\end{array}$ & $\begin{array}{c}0.014 \\
(0.117)\end{array}$ \\
\hline Middlesex & $\begin{array}{c}0.043 \\
(0.203)\end{array}$ & $\begin{array}{c}0.042 \\
(0.200)\end{array}$ & $\begin{array}{c}0.031 \\
(0.173)\end{array}$ \\
\hline Monmouth & $\begin{array}{c}0.008 \\
(0.090)\end{array}$ & $\begin{array}{c}0.007 \\
(0.085)\end{array}$ & $\begin{array}{c}0.006 \\
(0.077)\end{array}$ \\
\hline Morris & $\begin{array}{c}0.018 \\
(0.134)\end{array}$ & $\begin{array}{c}0.018 \\
(0.134)\end{array}$ & $\begin{array}{c}0.014 \\
(0.117)\end{array}$ \\
\hline Passaic & $\begin{array}{c}0.161 \\
{[0.367]}\end{array}$ & $\begin{array}{c}0.159 \\
{[0.366]}\end{array}$ & $\begin{array}{c}0.156 \\
{[0.364]}\end{array}$ \\
\hline Salem & $\begin{array}{c}0.014 \\
(0.119)\end{array}$ & $\begin{array}{c}0.015 \\
(0.120)\end{array}$ & $\begin{array}{c}0.025 \\
(0.156)\end{array}$ \\
\hline Sussex & 0.004 & 0.005 & 0.004 \\
\hline
\end{tabular}




\begin{tabular}{|c|c|c|c|}
\hline & $(0.066)$ & $(0.067)$ & $(0.063)$ \\
\hline \multirow[t]{2}{*}{ Union } & 0.051 & 0.051 & 0.064 \\
\hline & $(0.219)$ & $(0.219)$ & $(0.244)$ \\
\hline \multirow[t]{2}{*}{ Warren } & 0.038 & 0.038 & 0.045 \\
\hline & $(0.192)$ & (0.191) & $(0.208)$ \\
\hline \multirow[t]{2}{*}{ Unknown county } & 0.009 & 0.009 & 0.012 \\
\hline & $(0.095)$ & $(0.095)$ & $(0.111)$ \\
\hline \multirow[t]{2}{*}{ Glass } & 0.227 & 0.232 & 0.332 \\
\hline & $(0.419)$ & $(0.422)$ & $(0.471)$ \\
\hline \multirow[t]{2}{*}{ Mfg } & 0.192 & 0.196 & 0.180 \\
\hline & $(0.394)$ & $(0.397)$ & $(0.384)$ \\
\hline \multirow[t]{2}{*}{ Primary metals } & 0.101 & 0.103 & 0.068 \\
\hline & $(0.301)$ & $(0.304)$ & $(0.251)$ \\
\hline \multirow[t]{2}{*}{ Construction } & 0.070 & 0.071 & 0.091 \\
\hline & $(0.255)$ & $(0.257)$ & $(0.287)$ \\
\hline \multirow[t]{2}{*}{ Shoes } & 0.067 & 0.068 & 0.032 \\
\hline & $(0.250)$ & $(0.253)$ & $(0.175)$ \\
\hline \multirow[t]{2}{*}{ Textiles } & 0.151 & 0.154 & 0.097 \\
\hline & {$[0.358]$} & {$[0.361]$} & {$[0.295]$} \\
\hline \multirow[t]{2}{*}{ Transport } & 0.044 & 0.045 & 0.070 \\
\hline & $(0.205)$ & $(0.207)$ & $(0.255)$ \\
\hline \multirow[t]{2}{*}{ Clothing } & 0.058 & 0.059 & 0.040 \\
\hline & $(0.233)$ & $(0.236)$ & $(0.196)$ \\
\hline \multirow[t]{2}{*}{ Service } & 0.039 & 0.040 & 0.037 \\
\hline & $(0.195)$ & (0.197) & $(0.188)$ \\
\hline \multirow[t]{2}{*}{ Mining } & 0.015 & 0.016 & 0.016 \\
\hline & $(0.123)$ & $(0.124)$ & $(0.125)$ \\
\hline \multirow[t]{2}{*}{ Tobacco } & 0.014 & 0.015 & 0.023 \\
\hline & $(0.119)$ & $(0.120)$ & $(0.150)$ \\
\hline \multirow[t]{2}{*}{ Other industry } & 0.021 & 0.000 & 0.017 \\
\hline & $(0.144)$ & $(0.000)$ & $(0.130)$ \\
\hline \multirow[t]{2}{*}{ Labor } & 0.338 & 0.33 & 0.302 \\
\hline & {$[0.473]$} & {$[0.470]$} & {$[0.459]$} \\
\hline \multirow[t]{2}{*}{ Operative } & 0.491 & 0.502 & 0.542 \\
\hline & $(0.500)$ & $(0.500)$ & $(0.498)$ \\
\hline \multirow[t]{2}{*}{ Craft } & 0.153 & 0.150 & 0.144 \\
\hline & $(0.360)$ & $(0.358)$ & $(0.351)$ \\
\hline \multirow[t]{2}{*}{ Other skill } & 0.017 & 0.017 & 0.012 \\
\hline & $(0.128)$ & $(0.128)$ & (0.108) \\
\hline \multirow[t]{2}{*}{ y83 } & 0.143 & 0.145 & 0.165 \\
\hline & $(0.350)$ & $(0.352)$ & $(0.371)$ \\
\hline \multirow[t]{2}{*}{ y84 } & 0.349 & 0.349 & 0.250 \\
\hline & $(0.477)$ & $(0.477)$ & (0.433) \\
\hline \multirow[t]{2}{*}{ y85 } & 0.182 & 0.180 & 0.141 \\
\hline & $(0.386)$ & $(0.384)$ & $(0.348)$ \\
\hline y86 & 0.107 & 0.107 & 0.027 \\
\hline
\end{tabular}




\begin{tabular}{|c|c|c|c|}
\hline & $(0.310)$ & $(0.309)$ & $(0.102)$ \\
\hline \multirow[t]{2}{*}{ y88 } & 0.219 & 0.219 & 0.418 \\
\hline & {$[0.414]$} & {$[0.414]$} & [0.493] \\
\hline \multirow[t]{2}{*}{ One } & 0.029 & 0.028 & 0.020 \\
\hline & $(0.169)$ & $(0.165)$ & $(0.139)$ \\
\hline \multirow[t]{2}{*}{ Two } & 0.076 & 0.077 & 0.087 \\
\hline & {$[0.265]$} & {$[0.267]$} & {$[0.282]$} \\
\hline \multirow[t]{2}{*}{ Three } & 0.118 & 0.118 & 0.142 \\
\hline & $(0.323)$ & $(0.323)$ & $(0.350)$ \\
\hline \multirow[t]{2}{*}{ Four } & 0.151 & 0.152 & 0.177 \\
\hline & $(0.358)$ & $(0.359)$ & $(0.381)$ \\
\hline \multirow[t]{2}{*}{ Five/six } & 0.305 & 0.304 & 0.323 \\
\hline & $(0.460)$ & $(0.460)$ & $(0.468)$ \\
\hline \multirow[t]{2}{*}{ Seven +} & 0.320 & 0.320 & 0.251 \\
\hline & $(0.467)$ & $(0.467)$ & $(0.434)$ \\
\hline \multirow[t]{2}{*}{ Female } & 0.028 & 0.028 & 0.007 \\
\hline & $(0.164)$ & $(0.165)$ & $(0.085)$ \\
\hline \multirow[t]{2}{*}{ earningsoth } & 76.557 & 76.452 & 79.475 \\
\hline & $(147.084)$ & (147.058) & $(147.248)$ \\
\hline \multirow[t]{2}{*}{ Mutual saving bank } & 0.510 & 0.510 & 0.452 \\
\hline & $(0.500)$ & $(0.500)$ & $(0.498)$ \\
\hline \multirow[t]{2}{*}{ Building \& loan } & 0.844 & 0.846 & 0.853 \\
\hline & $(0.363)$ & $(0.361)$ & $(0.354)$ \\
\hline Observations & 2,940 & 2,878 & 1,523 \\
\hline
\end{tabular}




\begin{tabular}{|c|c|c|c|c|c|c|}
\hline \multicolumn{7}{|c|}{ Appendix Table 1A } \\
\hline \multicolumn{7}{|c|}{ Slack days from establishment reports and individual surveys } \\
\hline & \multicolumn{3}{|c|}{ Establishment reports } & \multicolumn{3}{|c|}{ Individual surveys } \\
\hline Industry & Mean & Std dev & Obs & Mean & Std dev & Obs \\
\hline Clothing & 50.26 & 28.25 & 49 & 20.07 & 35.89 & 170 \\
\hline Construction & 57.75 & 21.45 & 27 & 29.36 & 40.27 & 205 \\
\hline Glass & 57.31 & 37.28 & 66 & 25.29 & 35.08 & 667 \\
\hline Metals & 29.04 & 21.45 & 43 & 21.69 & 40.76 & 297 \\
\hline Manufacturing & 36.6 & 32.22 & 170 & 17.27 & 34.79 & 565 \\
\hline Mining & 9.64 & 18.29 & 15 & 1.22 & 4.66 & 45 \\
\hline Services & 19.55 & 10.2 & 2 & 8.53 & 21.45 & 116 \\
\hline Shoes & 31.32 & 20.48 & 62 & 28.71 & 36.63 & 197 \\
\hline Textiles & 32.01 & 24.61 & 55 & 31.62 & 40.58 & 445 \\
\hline Tobacco & 21.86 & 6.5 & 10 & 10.78 & 20.16 & 42 \\
\hline
\end{tabular}




\begin{tabular}{|c|c|c|c|c|c|c|}
\hline \multicolumn{7}{|c|}{ Appendix Table $2 \mathrm{~A}$} \\
\hline \multicolumn{7}{|c|}{ Reduced-form income and saving equations } \\
\hline & (1) & (2) & (3) & (4) & (5) & (6) \\
\hline VARIABLES & Income & Saving & Income & Saving & Est Income & Est Saving \\
\hline \multirow[t]{2}{*}{ Days lost } & $-1.482 * *$ & $-0.789 * *$ & $-1.543^{* *}$ & $-0.758^{* *}$ & $-2.134 * *$ & $-1.385^{* *}$ \\
\hline & {$[0.280]$} & {$[0.189]$} & {$[0.259]$} & {$[0.165]$} & {$[0.490]$} & {$[0.384]$} \\
\hline \multirow[t]{2}{*}{ Days lost sq } & $0.002 * *$ & $0.001^{* *}$ & $0.002 * *$ & $0.001 * *$ & $-0.001+$ & $-0.002^{* *}$ \\
\hline & {$[0.000]$} & {$[0.000]$} & {$[0.000]$} & {$[0.000]$} & {$[0.001]$} & {$[0.000]$} \\
\hline \multirow[t]{2}{*}{ Bergen } & $117.394 * *$ & $63.425^{* *}$ & $133.122 * *$ & $73.521 * *$ & -27.673 & -27.546 \\
\hline & [12.419] & [11.208] & [14.395] & {$[14.440]$} & {$[54.328]$} & [26.263] \\
\hline \multirow[t]{2}{*}{ Burlington } & 24.422 & -13.656 & 41.055 & -4.501 & 119.907 & -66.048 \\
\hline & [33.809] & [15.608] & [32.311] & [13.937] & [69.265] & [48.617] \\
\hline \multirow[t]{2}{*}{ Camden } & 21.638 & -13.752 & 24.215 & -10.023 & 76.072 & -9.157 \\
\hline & [43.839] & [18.066] & [44.731] & [17.812] & [53.585] & [36.224] \\
\hline \multirow[t]{2}{*}{ Cumberland } & 17.406 & 6.301 & 18.793 & 8.960 & $125.705^{* *}$ & 43.741 \\
\hline & [46.751] & [24.968] & [46.142] & [24.053] & [36.635] & [24.815] \\
\hline \multirow[t]{2}{*}{ Essex } & 18.332 & -23.836 & 21.813 & -20.125 & $83.234+$ & -16.173 \\
\hline & {$[37.476]$} & [19.909] & [33.462] & [17.713] & [38.499] & [21.850] \\
\hline \multirow[t]{2}{*}{ Gloucester } & 38.220 & 22.649 & 41.024 & 25.436 & 44.493 & -6.866 \\
\hline & [44.460] & [22.472] & [44.967] & [22.372] & [37.586] & [24.677] \\
\hline \multirow[t]{2}{*}{ Hudson } & $68.277^{*}$ & 18.878 & $68.525^{*}$ & 19.748 & $85.936^{* *}$ & 10.636 \\
\hline & [24.226] & [14.082] & [25.153] & [14.053] & [14.032] & [9.988] \\
\hline \multirow[t]{2}{*}{ Hunterdon } & 16.184 & 15.657 & 19.306 & 22.358 & -5.310 & -16.432 \\
\hline & [35.856] & [20.563] & [35.099] & [20.316] & [55.885] & [34.302] \\
\hline \multirow[t]{2}{*}{ Mercer } & $58.746+$ & $49.862^{*}$ & $57.258+$ & $50.056^{*}$ & $68.272 *$ & 77.929* \\
\hline & [30.459] & [17.067] & [31.176] & [18.454] & [30.294] & [29.468] \\
\hline \multirow[t]{2}{*}{ Middlesex } & -44.473 & 1.935 & -52.492 & 0.506 & 4.970 & $34.903+$ \\
\hline & [33.693] & [18.484] & [33.376] & [18.824] & [35.869] & [19.217] \\
\hline \multirow[t]{2}{*}{ Monmouth } & 38.888 & 26.017 & 63.282 & 43.332 & $133.759 * *$ & 53.469 \\
\hline & [39.697] & [23.474] & [46.221] & [27.228] & [38.213] & [32.715] \\
\hline \multirow[t]{2}{*}{ Morris } & 78.661 & 2.605 & 62.870 & -3.613 & -3.781 & -28.879 \\
\hline & [52.456] & [22.003] & [58.407] & [20.842] & [110.956] & [56.324] \\
\hline \multirow[t]{2}{*}{ Salem } & $100.895+$ & $72.567^{*}$ & $102.252+$ & $75.369^{*}$ & $192.308^{* *}$ & $110.832^{* *}$ \\
\hline & [49.985] & [25.886] & [50.228] & [25.650] & [46.370] & [31.832] \\
\hline \multirow[t]{2}{*}{ Sussex } & 20.660 & 3.643 & 23.960 & 9.905 & -130.570 & -73.775 \\
\hline & [118.710] & [41.873] & [112.276] & [38.973] & [90.195] & [56.017] \\
\hline \multirow[t]{2}{*}{ Union } & -43.329 & -18.326 & -36.862 & -12.254 & 1.857 & -7.047 \\
\hline & [25.402] & [10.595] & [26.223] & [10.476] & [13.702] & [12.921] \\
\hline \multirow[t]{2}{*}{ Warren } & 55.823 & 15.993 & 58.318 & 17.775 & $91.367+$ & -0.950 \\
\hline & [41.001] & [15.141] & [42.078] & [16.744] & [42.131] & [20.222] \\
\hline \multirow[t]{2}{*}{ Unknown county } & -9.872 & 20.872 & -6.378 & 33.304 & -5.313 & 17.528 \\
\hline & {$[56.257]$} & [40.235] & [53.386] & [39.355] & [48.158] & [51.610] \\
\hline \multirow[t]{2}{*}{ Glass } & $334.860 * *$ & $132.408^{* *}$ & $276.315^{* *}$ & $103.258^{* *}$ & $397.763^{* *}$ & $241.232^{* *}$ \\
\hline & [23.054] & {$[11.580]$} & [29.615] & [14.917] & [25.108] & [15.584] \\
\hline
\end{tabular}




\begin{tabular}{|c|c|c|c|c|c|c|}
\hline Mfg & $\begin{array}{c}104.271 * * \\
{[16.727]}\end{array}$ & $\begin{array}{c}42.099 * * \\
{[9.521]}\end{array}$ & $\begin{array}{c}64.434 * * \\
{[15.893]}\end{array}$ & $\begin{array}{c}21.469^{*} \\
{[7.784]}\end{array}$ & $\begin{array}{c}57.823^{* *} \\
{[11.823]}\end{array}$ & $\begin{array}{l}20.054+ \\
{[10.642]}\end{array}$ \\
\hline Primary metals & $\begin{array}{c}120.250 * * \\
{[23.369]}\end{array}$ & $\begin{array}{c}63.560^{* *} \\
{[12.394]}\end{array}$ & $\begin{array}{c}103.308^{* *} \\
{[20.036]}\end{array}$ & $\begin{array}{c}54.988 * * \\
{[10.153]}\end{array}$ & $\begin{array}{c}18.846 \\
{[34.979]}\end{array}$ & $\begin{array}{c}41.613 \\
{[23.262]}\end{array}$ \\
\hline Construction & $\begin{array}{c}84.287 * * \\
{[25.190]}\end{array}$ & $\begin{array}{c}42.421 * * \\
{[13.428]}\end{array}$ & $\begin{array}{l}49.706^{*} \\
{[19.535]}\end{array}$ & $\begin{array}{c}25.050^{*} \\
{[9.853]}\end{array}$ & $\begin{array}{c}31.450 \\
{[30.804]}\end{array}$ & $\begin{array}{c}17.993 \\
{[21.104]}\end{array}$ \\
\hline Shoes & $\begin{array}{c}198.313 * * \\
{[49.353]}\end{array}$ & $\begin{array}{c}99.072 * * \\
{[26.569]}\end{array}$ & $\begin{array}{c}176.154 * * \\
{[46.153]}\end{array}$ & $\begin{array}{c}86.625^{* *} \\
{[23.882]}\end{array}$ & $\begin{array}{c}235.723 * \\
{[92.920]}\end{array}$ & $\begin{array}{c}210.627 * * \\
{[64.775]}\end{array}$ \\
\hline Transport & $\begin{array}{c}101.487 * * \\
{[23.550]}\end{array}$ & $\begin{array}{c}45.845 * * \\
{[13.244]}\end{array}$ & $\begin{array}{c}88.866^{* *} \\
{[20.490]}\end{array}$ & $\begin{array}{c}37.743^{* *} \\
{[11.374]}\end{array}$ & $\begin{array}{l}89.680^{*} \\
{[39.636]}\end{array}$ & $\begin{array}{c}45.857 \\
{[31.483]}\end{array}$ \\
\hline Clothing & $\begin{array}{c}21.607 \\
{[22.435]}\end{array}$ & $\begin{array}{c}4.379 \\
{[13.881]}\end{array}$ & $\begin{array}{c}2.500 \\
{[19.923]}\end{array}$ & $\begin{array}{c}-5.608 \\
{[11.903]}\end{array}$ & $\begin{array}{c}91.456^{* *} \\
{[17.587]}\end{array}$ & $\begin{array}{c}95.185^{* *} \\
{[10.463]}\end{array}$ \\
\hline Service & $\begin{array}{c}111.735 * * \\
{[20.408]}\end{array}$ & $\begin{array}{c}43.189 * * \\
{[10.696]}\end{array}$ & $\begin{array}{c}76.724 * * \\
{[15.145]}\end{array}$ & $\begin{array}{c}23.393 * \\
{[7.849]}\end{array}$ & $\begin{array}{l}82.569+ \\
{[39.143]}\end{array}$ & $\begin{array}{l}27.820 \\
{[26.397]}\end{array}$ \\
\hline Mining & $\begin{array}{l}-51.176 \\
{[41.622]}\end{array}$ & $\begin{array}{c}10.700 \\
{[20.257]}\end{array}$ & $\begin{array}{l}-78.486 \\
{[45.918]}\end{array}$ & $\begin{array}{c}-2.187 \\
{[21.379]}\end{array}$ & $\begin{array}{l}-46.632 \\
{[67.540]}\end{array}$ & $\begin{array}{c}9.262 \\
{[34.262]}\end{array}$ \\
\hline Tobacco & $\begin{array}{c}65.790^{* *} \\
{[16.060]}\end{array}$ & $\begin{array}{c}15.038 \\
{[10.762]}\end{array}$ & $\begin{array}{l}38.334^{*} \\
{[16.546]}\end{array}$ & $\begin{array}{c}1.344 \\
{[10.581]}\end{array}$ & $\begin{array}{c}12.408 \\
{[13.358]}\end{array}$ & $\begin{array}{l}-2.549 \\
{[9.412]}\end{array}$ \\
\hline Other industry & $\begin{array}{l}80.581 * \\
{[35.349]}\end{array}$ & $\begin{array}{l}42.134+ \\
{[19.373]}\end{array}$ & & & $\begin{array}{c}58.468 \\
{[55.571]}\end{array}$ & $\begin{array}{c}69.934 \\
{[41.691]}\end{array}$ \\
\hline Operative & $\begin{array}{c}170.103 * \\
{[59.381]}\end{array}$ & $\begin{array}{l}60.454+ \\
{[30.799]}\end{array}$ & $\begin{array}{c}167.968^{*} \\
{[60.528]}\end{array}$ & $\begin{array}{l}58.757+ \\
{[31.127]}\end{array}$ & $\begin{array}{l}256.003 * \\
{[102.542]}\end{array}$ & $\begin{array}{l}119.015 \\
{[71.524]}\end{array}$ \\
\hline Craft & $\begin{array}{c}185.931 * * \\
{[23.932]}\end{array}$ & $\begin{array}{c}58.390^{* *} \\
{[12.224]}\end{array}$ & $\begin{array}{c}176.648^{* *} \\
{[23.874]}\end{array}$ & $\begin{array}{c}53.173^{* *} \\
{[11.617]}\end{array}$ & $\begin{array}{c}240.218^{* *} \\
{[41.752]}\end{array}$ & $\begin{array}{l}82.872^{*} \\
{[27.510]}\end{array}$ \\
\hline Other skill & $\begin{array}{c}109.468^{*} \\
{[36.583]}\end{array}$ & $\begin{array}{l}52.524^{*} \\
{[21.523]}\end{array}$ & $\begin{array}{l}98.720^{*} \\
{[35.033]}\end{array}$ & $\begin{array}{l}53.034 * \\
{[23.573]}\end{array}$ & $\begin{array}{c}109.102 * \\
{[42.075]}\end{array}$ & $\begin{array}{c}36.731 \\
{[58.834]}\end{array}$ \\
\hline y83 & $\begin{array}{l}-10.920 \\
{[28.422]}\end{array}$ & $\begin{array}{l}-21.973 \\
{[12.303]}\end{array}$ & $\begin{array}{c}-1.655 \\
{[26.531]}\end{array}$ & $\begin{array}{l}-17.492 \\
{[10.748]}\end{array}$ & $\begin{array}{c}-80.737^{* *} \\
{[21.408]}\end{array}$ & $\begin{array}{r}-64.157^{* *} \\
{[13.698]}\end{array}$ \\
\hline y84 & $\begin{array}{c}-19.044+ \\
{[10.488]}\end{array}$ & $\begin{array}{c}-14.639 \\
{[8.820]}\end{array}$ & $\begin{array}{c}-25.191 * \\
{[9.826]}\end{array}$ & $\begin{array}{l}-18.389 \\
{[12.776]}\end{array}$ & $\begin{array}{c}-38.135+ \\
{[18.437]}\end{array}$ & $\begin{array}{l}-27.126 \\
{[26.673]}\end{array}$ \\
\hline y85 & $\begin{array}{c}-49.605^{*} \\
{[17.727]}\end{array}$ & $\begin{array}{l}-28.423 \\
{[16.089]}\end{array}$ & $\begin{array}{l}-22.366 \\
{[20.920]}\end{array}$ & $\begin{array}{l}-15.293 \\
{[18.340]}\end{array}$ & $\begin{array}{c}-122.931 * * \\
{[35.409]}\end{array}$ & $\begin{array}{r}-108.062^{*} \\
{[41.913]}\end{array}$ \\
\hline y86 & $\begin{array}{c}-8.086 \\
{[16.332]}\end{array}$ & $\begin{array}{c}-44.278^{*} \\
{[15.354]}\end{array}$ & $\begin{array}{c}-3.701 \\
{[15.919]}\end{array}$ & $\begin{array}{l}-41.132^{*} \\
{[14.787]}\end{array}$ & $\begin{array}{c}399.638^{* *} \\
{[36.631]}\end{array}$ & $\begin{array}{c}335.675^{* *} \\
{[33.188]}\end{array}$ \\
\hline One & $\begin{array}{l}-13.095 \\
{[20.328]}\end{array}$ & $\begin{array}{l}36.594+ \\
{[17.360]}\end{array}$ & $\begin{array}{l}-12.644 \\
{[21.497]}\end{array}$ & $\begin{array}{l}38.060+ \\
{[18.252]}\end{array}$ & $\begin{array}{c}-4.185 \\
{[34.288]}\end{array}$ & $\begin{array}{c}65.055^{* *} \\
{[15.487]}\end{array}$ \\
\hline Three & $\begin{array}{c}45.971 * * \\
{[10.773]}\end{array}$ & $\begin{array}{l}-1.330 \\
{[7.459]}\end{array}$ & $\begin{array}{c}46.617^{* *} \\
{[11.443]}\end{array}$ & $\begin{array}{l}-3.081 \\
{[7.503]}\end{array}$ & $\begin{array}{c}21.198 \\
{[11.973]}\end{array}$ & $\begin{array}{l}-28.606 \\
{[16.798]}\end{array}$ \\
\hline Four & $\begin{array}{l}63.972^{*} \\
{[22.062]}\end{array}$ & $\begin{array}{c}-17.113+ \\
{[8.410]}\end{array}$ & $\begin{array}{l}65.078^{*} \\
{[21.733]}\end{array}$ & $\begin{array}{c}-16.860+ \\
{[8.764]}\end{array}$ & $\begin{array}{l}20.396 \\
{[20.231]}\end{array}$ & $\begin{array}{c}-59.006^{* *} \\
{[14.490]}\end{array}$ \\
\hline Five/six & $\begin{array}{c}71.831 * * \\
{[10.215]}\end{array}$ & $\begin{array}{c}-49.383^{* *} \\
{[13.663]}\end{array}$ & $\begin{array}{c}69.120^{* *} \\
{[8.733]}\end{array}$ & $\begin{array}{c}-51.364 * * \\
{[14.116]}\end{array}$ & $\begin{array}{l}34.074+ \\
{[15.794]}\end{array}$ & $\begin{array}{r}-76.329^{* *} \\
{[18.280]}\end{array}$ \\
\hline Seven + & $\begin{array}{c}50.403 * * \\
{[15.376]}\end{array}$ & $\begin{array}{c}-42.706^{*} \\
{[15.740]}\end{array}$ & $\begin{array}{c}50.693 * * \\
{[13.919]}\end{array}$ & $\begin{array}{l}-43.084 * \\
{[16.347]}\end{array}$ & $\begin{array}{c}63.003 \\
{[38.739]}\end{array}$ & $\begin{array}{c}-44.705^{* *} \\
{[9.863]}\end{array}$ \\
\hline Female & $\begin{array}{c}-205.210^{* *} \\
{[31.971]}\end{array}$ & $\begin{array}{c}-1.190 \\
{[24.772]}\end{array}$ & $\begin{array}{c}-207.446 * * \\
{[24.236]}\end{array}$ & $\begin{array}{c}-1.216 \\
{[23.058]}\end{array}$ & $\begin{array}{c}-158.598^{* *} \\
{[41.756]}\end{array}$ & $\begin{array}{c}13.042 \\
{[40.660]}\end{array}$ \\
\hline
\end{tabular}




\begin{tabular}{lcccccc}
\hline earningsoth & $-0.198^{*}$ & $0.253^{* *}$ & $-0.194^{*}$ & $0.254^{* *}$ & $-0.330^{*}$ & $0.187^{*}$ \\
& {$[0.065]$} & {$[0.024]$} & {$[0.065]$} & {$[0.026]$} & {$[0.113]$} & {$[0.061]$} \\
Mutual saving bank & 37.953 & 4.614 & $41.799+$ & 7.182 & 52.760 & 9.188 \\
& {$[22.536]$} & {$[11.861]$} & {$[22.120]$} & {$[11.546]$} & {$[30.786]$} & {$[15.546]$} \\
Building \& loan & $48.444^{* *}$ & -5.378 & $46.852^{* *}$ & -4.973 & $47.535^{* *}$ & -13.289 \\
& {$[13.428]$} & {$[8.387]$} & {$[13.293]$} & {$[8.491]$} & {$[7.675]$} & {$[11.320]$} \\
Constant & $239.917^{* *}$ & 6.187 & $243.922^{* *}$ & 7.096 & $198.290^{*}$ & -12.464 \\
& {$[43.753]$} & {$[10.964]$} & {$[40.501]$} & {$[10.151]$} & {$[65.586]$} & {$[21.853]$} \\
& & & & & & \\
Observations & 2,940 & 2,940 & 2,878 & 2,878 & 1,523 & 1,523 \\
R-squared & 0.471 & 0.279 & 0.475 & 0.278 & 0.430 & 0.271 \\
\hline
\end{tabular}




\begin{tabular}{|c|c|c|c|c|}
\hline \multicolumn{5}{|c|}{ Appendix Table 3A } \\
\hline \multicolumn{5}{|c|}{ Maximum likelihood estimates using occupational prestige scores } \\
\hline & (1) & (2) & (3) & (4) \\
\hline VARIABLES & income & saving & income & saving \\
\hline \multirow[t]{2}{*}{ Days lost } & $-1.438^{* *}$ & $-0.770^{* *}$ & $-2.294 * *$ & $-1.203^{* *}$ \\
\hline & {$[0.100]$} & {$[0.066]$} & {$[0.145]$} & {$[0.111]$} \\
\hline \multirow[t]{2}{*}{ Days lost sq } & $0.002 * *$ & $0.001 * *$ & $0.003^{* *}$ & $0.001 * *$ \\
\hline & {$[0.000]$} & {$[0.000]$} & {$[0.000]$} & {$[0.000]$} \\
\hline \multirow[t]{2}{*}{ Bergen } & 55.939 & $40.071+$ & -209.328 & -199.590 \\
\hline & {$[36.260]$} & [23.827] & {$[178.447]$} & [136.219] \\
\hline \multirow[t]{2}{*}{ Burlington } & 35.949 & -6.659 & $-78.502 *$ & $-63.231 *$ \\
\hline & [24.595] & [16.162] & [39.919] & [30.473] \\
\hline \multirow[t]{2}{*}{ Camden } & $42.640^{* *}$ & -3.442 & $-50.108+$ & $-42.843^{*}$ \\
\hline & {$[16.025]$} & [10.530] & [28.121] & {$[21.467]$} \\
\hline \multirow[t]{2}{*}{ Cumberland } & 34.316 & 15.415 & $-66.270+$ & $-54.515^{*}$ \\
\hline & [21.756] & [14.296] & [36.190] & [27.626] \\
\hline \multirow[t]{2}{*}{ Essex } & 12.977 & $-23.369 *$ & $-99.018^{* *}$ & $-83.306^{* *}$ \\
\hline & [16.559] & [10.882] & [28.488] & [21.746] \\
\hline \multirow[t]{2}{*}{ Gloucester } & $55.969 *$ & $31.961 *$ & -41.235 & -26.747 \\
\hline & {$[24.450]$} & {$[16.067]$} & {$[37.445]$} & {$[28.584]$} \\
\hline \multirow[t]{2}{*}{ Hudson } & $72.988^{* *}$ & $22.392+$ & $61.774+$ & 1.445 \\
\hline & [17.519] & [11.512] & [35.008] & [26.724] \\
\hline \multirow[t]{2}{*}{ Hunterdon } & 7.329 & 11.882 & $-101.988+$ & -60.404 \\
\hline & [28.334] & [18.619] & [60.469] & [46.160] \\
\hline \multirow[t]{2}{*}{ Mercer } & 19.417 & $35.882^{*}$ & $-90.960^{*}$ & 11.011 \\
\hline & {$[25.837]$} & [16.978] & [42.491] & [32.436] \\
\hline \multirow[t]{2}{*}{ Middlesex } & $-70.712^{* *}$ & -4.806 & $-231.443^{* *}$ & $-86.183^{* *}$ \\
\hline & [21.106] & [13.869] & [40.785] & [31.133] \\
\hline \multirow[t]{2}{*}{ Monmouth } & 17.300 & 21.074 & -110.469 & -77.423 \\
\hline & [44.254] & [29.080] & [68.825] & [52.538] \\
\hline \multirow[t]{2}{*}{ Morris } & 49.643 & -3.166 & $119.776+$ & -42.984 \\
\hline & [38.064] & [25.013] & [64.147] & {$[48.967]$} \\
\hline \multirow[t]{2}{*}{ Salem } & $110.886^{* *}$ & $77.363^{* *}$ & -15.746 & 7.856 \\
\hline & [36.362] & [23.894] & [45.739] & [34.915] \\
\hline \multirow[t]{2}{*}{ Sussex } & 26.777 & 11.364 & -154.026 & -102.337 \\
\hline & [56.911] & [37.398] & [131.325] & [100.248] \\
\hline \multirow[t]{2}{*}{ Union } & $-49.737 *$ & -21.441 & $-178.245^{* *}$ & $-98.764 * *$ \\
\hline & [19.838] & [13.036] & [40.281] & [30.749] \\
\hline \multirow[t]{2}{*}{ Warren } & $71.088^{* *}$ & 23.092 & $-96.542^{*}$ & -37.859 \\
\hline & {$[26.003]$} & [17.087] & [47.002] & [35.879] \\
\hline \multirow[t]{2}{*}{ Unknown county } & 5.348 & 28.722 & $-170.473^{* *}$ & -68.855 \\
\hline & [40.930] & [26.896] & [55.632] & [42.467] \\
\hline \multirow[t]{2}{*}{ Glass } & $134.461^{* *}$ & $64.176^{* *}$ & $386.374 * *$ & $169.262^{* *}$ \\
\hline & [20.924] & [13.750] & [44.093] & [33.659] \\
\hline Mfg & $27.595+$ & $17.132+$ & $188.453 * *$ & $79.459 * *$ \\
\hline
\end{tabular}




\begin{tabular}{|c|c|c|c|c|}
\hline & [15.644] & {$[10.280]$} & {$[39.342]$} & [30.032] \\
\hline \multirow{2}{*}{ Primary metals } & $64.224 * *$ & $45.546^{* *}$ & $173.499 * *$ & $89.486 * *$ \\
\hline & {$[16.662]$} & [10.949] & {$[41.146]$} & [31.409] \\
\hline \multirow[t]{2}{*}{ Construction } & $55.609 * *$ & $33.878^{* *}$ & $168.422^{* *}$ & $69.770 *$ \\
\hline & {$[18.507]$} & [12.162] & [40.369] & [30.816] \\
\hline \multirow[t]{2}{*}{ Shoes } & 22.680 & $29.827+$ & $84.925+$ & 63.186 \\
\hline & [23.288] & [15.303] & [50.844] & [38.812] \\
\hline \multirow[t]{2}{*}{ Transport } & 32.990 & $23.523+$ & 88.449 & $85.812+$ \\
\hline & [21.270] & {$[13.977]$} & [63.916] & [48.791] \\
\hline \multirow{2}{*}{ Clothing } & $-160.100 * *$ & $-60.722^{* *}$ & -48.884 & 0.388 \\
\hline & [22.445] & [14.749] & [41.481] & [31.665] \\
\hline \multirow[t]{2}{*}{ Service } & 9.709 & 14.356 & $217.148^{* *}$ & $109.420+$ \\
\hline & [22.277] & [14.639] & {$[77.070]$} & [58.832] \\
\hline \multirow[t]{2}{*}{ Mining } & -43.886 & 5.385 & $-130.082+$ & 57.216 \\
\hline & {$[40.671]$} & {$[26.726]$} & [78.429] & [59.869] \\
\hline \multirow[t]{2}{*}{ Tobacco } & $89.622^{* *}$ & 22.394 & $147.140^{* *}$ & 54.515 \\
\hline & [32.345] & [21.255] & [44.853] & [34.239] \\
\hline \multirow[t]{2}{*}{ Other industry } & -2.747 & 12.125 & $162.422^{* *}$ & 95.989* \\
\hline & {$[26.209]$} & {$[17.222]$} & [54.345] & [41.485] \\
\hline \multirow[t]{2}{*}{ sei2 } & $75.065^{* *}$ & $31.531^{* *}$ & 48.104 & 22.065 \\
\hline & {$[15.368]$} & [10.099] & [39.186] & [29.913] \\
\hline \multirow[t]{2}{*}{ sei3 } & $80.272^{* *}$ & $14.068+$ & $79.425^{*}$ & 24.851 \\
\hline & [11.979] & {$[7.872]$} & {$[32.363]$} & [24.704] \\
\hline \multirow[t]{2}{*}{ sei4 } & $268.599 * *$ & $92.630^{* *}$ & $130.655^{* *}$ & $47.384+$ \\
\hline & [15.825] & [10.399] & [37.616] & [28.715] \\
\hline \multirow[t]{2}{*}{ sei5 } & $155.586^{* *}$ & $56.277 * *$ & $126.937^{* *}$ & $73.893^{*}$ \\
\hline & [13.455] & [8.841] & [39.265] & [29.973] \\
\hline \multirow[t]{2}{*}{ y83 } & 6.270 & $-14.904+$ & -2.436 & -17.046 \\
\hline & [12.556] & [8.251] & [20.188] & [15.411] \\
\hline \multirow[t]{2}{*}{ y84 } & -3.381 & -8.621 & $45.660^{*}$ & 2.891 \\
\hline & {$[10.709]$} & {$[7.037]$} & [18.209] & [13.900] \\
\hline \multirow[t]{2}{*}{ y85 } & $-41.243^{* *}$ & $-24.579 * *$ & -1.839 & 2.017 \\
\hline & [11.973] & [7.868] & [19.935] & {$[15.217]$} \\
\hline \multirow[t]{2}{*}{ y86 } & -2.608 & $-42.469 * *$ & 21.762 & -7.038 \\
\hline & [13.673] & [8.985] & [25.926] & [19.791] \\
\hline \multirow[t]{2}{*}{ One } & -18.308 & $33.789 *$ & $-73.417+$ & -8.348 \\
\hline & [24.460] & {$[16.073]$} & [43.586] & [33.271] \\
\hline \multirow[t]{2}{*}{ Three } & $36.886^{*}$ & -5.169 & 37.310 & -2.049 \\
\hline & [16.084] & [10.569] & [26.793] & [20.453] \\
\hline \multirow[t]{2}{*}{ Four } & $57.870^{* *}$ & $-19.814+$ & $55.161 *$ & $-39.411 *$ \\
\hline & [15.456] & [10.157] & [25.980] & [19.832] \\
\hline \multirow[t]{2}{*}{ Five/six } & $66.018^{* *}$ & $-52.000 * *$ & 24.971 & $-88.353^{* *}$ \\
\hline & [14.394] & [9.459] & [24.242] & [18.506] \\
\hline \multirow[t]{2}{*}{ Seven +} & $41.921^{* *}$ & $-46.724 * *$ & 1.334 & $-91.973^{* *}$ \\
\hline & [14.875] & [9.775] & [24.392] & [18.620] \\
\hline Female & $-200.153^{* *}$ & -1.006 & $-222.156^{* *}$ & 2.040 \\
\hline
\end{tabular}




\begin{tabular}{lcccc}
\hline & {$[23.729]$} & {$[15.593]$} & {$[35.900]$} & {$[27.405]$} \\
earningsoth & $-0.208^{* *}$ & $0.251^{* *}$ & $-0.129 * *$ & $0.329^{* *}$ \\
Decline age 30 & {$[0.025]$} & {$[0.017]$} & {$[0.040]$} & {$[0.030]$} \\
& & & -41.718 & -6.101 \\
decline35 & & & {$[31.849]$} & {$[24.312]$} \\
& & & $-42.721^{*}$ & $-41.906^{* *}$ \\
decline45 & & & {$[18.998]$} & {$[14.503]$} \\
& & & $-89.289^{* *}$ & $-77.412^{* *}$ \\
decline50 & & {$[15.513]$} & {$[11.842]$} \\
& & & $-86.605^{* *}$ & $-87.456^{* *}$ \\
decline55 & & & {$[23.536]$} & {$[17.966]$} \\
& & & $-80.353^{* *}$ & $-52.718^{* *}$ \\
decline60 & & & -8.247 & -40.973 \\
& & & {$[58.418]$} & {$[44.594]$} \\
Mutual saving bank & $36.839^{*}$ & 4.570 & $46.067+$ & -8.174 \\
Building \& loan & {$[14.504]$} & {$[9.531]$} & {$[24.461]$} & {$[18.672]$} \\
& $41.405^{* *}$ & -8.571 & $34.170+$ & -12.857 \\
Constant & {$[13.283]$} & {$[8.728]$} & {$[19.164]$} & {$[14.629]$} \\
& $337.023^{* *}$ & $40.264 * *$ & $438.373 * *$ & $121.884 * *$ \\
& {$[22.369]$} & {$[14.699]$} & {$[39.253]$} & {$[29.964]$} \\
Observations & & & & \\
R-squared & 2,940 & 2,940 & 1,143 & 1,143 \\
\hline
\end{tabular}




\section{Appendix Figure A1}

Current saving rate vs estimated saving rate

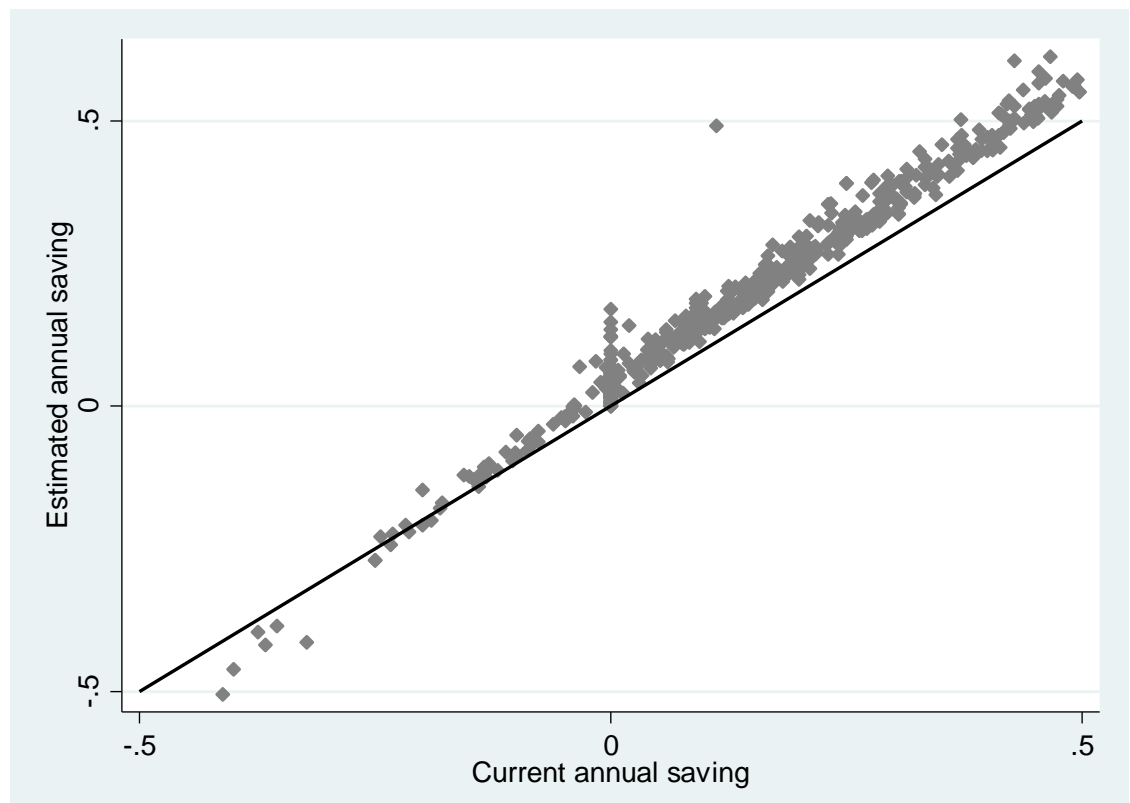

Source: author's calculations from data reported in NJBSLI (1883-1888).

Notes: the horizontal axis measures saving as current household income less current total expenditure. The vertical axis measures estimated saving rate, after making imputations for insurance premiums and rental value of housing. The solid line is the 45-degree line. The diagram reveals the concordance between current and estimated saving, though the latter is generally higher, except at high dissaving rates. 